\title{
Phenotypic and genotypic characterization of Vibrio viscosus sp. nov. and Vibrio wodanis sp. nov. isolated from Atlantic salmon (Salmo salar) with 'winter ulcer'
}

\author{
Tor Lunder, ${ }^{1 \dagger}$ Henning Sørum, ${ }^{2}$ Gudmund Holstad, ${ }^{1}$ \\ Arnold G. Steigerwalt, ${ }^{3}$ Petter Mowinckel ${ }^{4}$ and Don J. Brenner ${ }^{3}$
}

Author for correspondence: Henning Sørum. Tel: +47229647 70. Fax: +4722964818. e-mail: henning.sorum@veths.no

\footnotetext{
1 National Veterinary Institute, PO Box 8156 Dep., N-0033 Oslo, Norway

2 Norwegian College of Veterinary Medicine, Department of Pharmacology, Microbiology and Food Hygiene, PO Box 8146 Dep., N-0033 Oslo, Norway

3 Meningitis and Special Pathogens Branch, Division of Bacterial and Mycotic Diseases, National Center for Infectious Diseases, Centers for Disease Control and Prevention, Atlanta, GA 30333, USA

4 Medstat, $\mathrm{N}-2010$ Strømmen, Norway
}

\begin{abstract}
Two groups of Vibrio strains isolated from Atlantic salmon with 'winter ulcer' were characterized phenotypically and genotypically. The data obtained indicated that each of the two groups represented a new species in the genus Vibrio. The names Vibrio viscosus sp. nov. [type strain NVI $88 / 478^{\top}$ ( = NCIMB $\left.13584^{\top}\right)$ ] and Vibrio wodanis sp. nov. [type strain NVI 88/441 ${ }^{\top}\left(=\right.$ NCIMB $13582^{\top}$ )] are proposed for the new species. $V$. viscosus strains exhibited a similar total DNA RFLP pattern and a similar plasmid DNA profile. DNA relatedness (hydroxyapatite method) of the $V$. viscosus type strain to nine other $V$. viscosus strains was $81-93 \%$ at $60{ }^{\circ} \mathrm{C}$. Divergence within related sequences was $0.0-1.5 \%$ and relatedness at $75{ }^{\circ} \mathrm{C}$ was $74-100 \%$. $V$. wodanis strains exhibited marked heterogeneity on the basis of RFLP analysis and plasmid profiles. DNA relatedness of the $V$. wodanis type strain to 10 other $V$. wodanis strains was $66-94 \%$ at $60{ }^{\circ} \mathrm{C}$. Divergence within related sequences was $0.0-1.5 \%$ and relatedness at $75{ }^{\circ} \mathrm{C}$ was 55-97\%. Relatedness between $V$. viscosus and $V$. wodanis type strains was approximately $20 \%$. Among other Vibrio species, the closest relative of $V$. viscosus was Vibrio marinus (ATCC 15381') (43\% relatedness at $60^{\circ} \mathrm{C}$ ) and that of $V$. wodanis was Vibrio logei (ATCC 15382) $\left(57 \%\right.$ relatedness at $\left.60^{\circ} \mathrm{C}\right)$. These same pairs were the closest phenotypic relatives. DNA sequence analysis of the 16S rRNA gene of $V$. viscosus indicated an intimate relationship to $V$. marinus. A total evaluation of the results, however, supports $V$. viscosus to be a separate species in the genus Vibrio. The analysis of the sequence of the 16S rRNA gene of $v$. wodanis supports that $v$. logei (ATCC 15382) was the most related species. Ability to degrade casein, oxidative production of acid from trehalose and production of lysine decarboxylase are important biochemical tests that will differentiate between V. viscosus, V. wodanis, V. marinus (ATCC 15381') and V. logei (ATCC 15382).
\end{abstract}

\section{INTRODUCTION}

'Winter ulcer' is a disease affecting sea-farmed Atlantic salmon (Salmo salar) (Lunder et al., 1995). The disease

†Present address: TINE Norwegian Diaries, PO Box 58, N-1431 Ås, Norway.

Abbreviations: AMPPD, 3-(2'-spiroadamantane)-4-methoxy-4-(3"phosphoryloxy)-phenyl-1,2-dioethane; HMO, hypothetical mean organism.

The EMBL accession numbers for the $16 \mathrm{~S}$ rDNA sequences of Vibrio viscosus $88 / 478^{\top}$ and Vibrio wodanis $88 / 441^{\top}$ are $\mathrm{AJ} 132226$ and AJ132227, respectively. is characterized by skin ulcers confined to scalecovered parts of the body surface, most frequently along the sides of the fish. Winter ulcer occurs mainly during the winter season and is seen in farms with net pens in the sea and in land-located farms with sea water. The disease is observed all along the Norwegian coast from Finnmark county in the north to the Swedish border in the south-east. The mortality is limited, but the disease has economic significance due to lowered quality of the fish.

In a bacteriological examination of affected Atlantic salmon suffering from winter ulcer, two main groups 
of bacteria were isolated (Lunder et al., 1995). A limited characterization indicated that both groups belonged to the genus Vibrio, the groups being termed Vibrio sp. 1 and Vibrio sp. 2, respectively. Experimental infection with Vibrio sp. 1 induced a disease similar to winter ulcer in Atlantic salmon, while inoculation with Vibrio sp. 2 had no effect. Cohabitation experiments also showed that winter ulcer can be transmitted from diseased to healthy individuals. There are several fishpathogenic bacteria that are members of the genus Vibrio, such as Vibrio alginolyticus, Vibrio anguillarum, Vibrio carchariae, Vibrio damsela, Vibrio ordalii, Vibrio parahaemolyticus, Vibrio salmonicida and Vibrio vulnificus biotype 2 (Colwell \& Grimes, 1994; Egidius et al., 1986).

The aim of this study was to obtain information about phenotypic and genotypic properties of the bacterial strains isolated from Atlantic salmon with winter ulcer. We also wanted to determine the relationship between these strains and other fish-pathogenic and psychrophilic species of the genus Vibrio.

\section{METHODS}

Bacterial strains. Eleven and 31 strains of Vibrio sp. 1 and Vibrio sp. 2, respectively, isolated in a previous investigation from Atlantic salmon with winter ulcer in eight different fish farms, were selected randomly for the present study (Lunder et al., 1995). Furthermore, nine strains of Vibrio sp. 1 and four strains of Vibrio sp. 2 were randomly selected from the stock collection of bacteria at the National Veterinary Institute, Oslo, Norway. The strains were isolated from fish at numerous locations along the Norwegian coast during the winter season in the period from 1988 to 1990 . One Vibrio sp. 1 strain $(89 / 2148)$ was isolated from plaice (Pleuronectes platessa), the other strains were isolated from Atlantic salmon. One strain of $V$. salmonicida was isolated from a salmon with winter ulcer. The type and reference strains used in this study are listed in Table 1.

Vibrio logei ATCC 15382 and $V$. logei NCMB 1143 originated from the same strain, PS 207, isolated from the skin of Pacific cod Gadus macrocephalus. All strains included in the study were examined in the tests presented below.

The strains were stored as frozen cultures at $-80{ }^{\circ} \mathrm{C}$ in brain-heart infusion broth (BHIB) (Difco) containing $2 \%$ $\mathrm{NaCl}$ and $30 \%$ glycerol and maintained on brain-heart infusion agar (BHIA) (Difco) slants containing $2 \% \mathrm{NaCl}$ at $4{ }^{\circ} \mathrm{C}$. All the Vibrio sp. 1 and Vibrio sp. 2 strains have been investigated in all the methods used in the study.

Physiological and biochemical characterization. Cells from a 2-d-old culture on heart infusion agar (Difco) containing $2 \% \mathrm{NaCl}$ and $5 \%$ bovine blood (BA) were used in all tests. Unless otherwise noted the final $\mathrm{NaCl}$ content of the test media was adjusted to $2 \%$. All the test media, except the media used to determine the temperature range for growth, were incubated at $15^{\circ} \mathrm{C}$. The tests were read every other day for $14 \mathrm{~d}$. Each strain was examined for 85 different characters as listed in Table 2. The tests were performed as described by West \& Colwell (1984) with the following exceptions. Colony morphology and haemolysis were observed on BA. Production of DNases and caseinases was assayed from supernatants of BHIB cultures grown at $15^{\circ} \mathrm{C}$ under constant shaking for $3 \mathrm{~d}$. The supernatants were inoculated onto agar plates containing $0 \cdot 3 \mathrm{~g} \mathrm{DNA}^{-1}$ and $9 \cdot 18 \times 10^{-5} \mathrm{~g}$ toluidine blue $1^{-1}$ and then onto sodium caseinate $\left(5 \mathrm{~g} \mathrm{l}^{-1}\right)$ plates before incubation at $37^{\circ} \mathrm{C}$ overnight (Lachica et al., 1971; Sandvik $\&$ Hagen, 1968). The ability to grow at different temperatures was tested on BA at $4,15,22,25$ and $30^{\circ} \mathrm{C}$. Acid production from carbohydrates was determined in a medium containing $0.7 \%$ of the actual sugar, $6 \mathrm{ml} 0.2 \%$ phenol red solution $1^{-1}$, $2 \cdot 7 \mathrm{~g}$ nutrient broth (Difco) $\mathrm{l}^{-1}, 5 \mathrm{~g}$ proteose peptone (Difco) $\mathrm{l}^{-1}, 20 \mathrm{~g} \mathrm{NaCl}^{-1}, 0.3 \mathrm{~g} \mathrm{~K}_{2} \mathrm{HPO}_{4} \cdot 2 \mathrm{H}_{2} \mathrm{Ol}^{-1}$ and $10 \mathrm{ml}$ mineral salt solution $\mathrm{l}^{-1}$ containing (g $\left.\mathrm{g}^{-1}\right) \mathrm{MgCl}_{2} \cdot 6 \mathrm{H}_{2} \mathrm{O}$ (20), $\mathrm{CaCl}_{2} \cdot 2 \mathrm{H}_{2} \mathrm{O}(5 \cdot 7), \mathrm{FeCl}_{2} \cdot 4 \mathrm{H}_{2} \mathrm{O}(0 \cdot 5), \mathrm{ZnSO}_{4} \cdot 7 \mathrm{H}_{2} \mathrm{O}(0 \cdot 5)$, $\mathrm{CoCl}_{2} \cdot 6 \mathrm{H}_{2} \mathrm{O}(0 \cdot 25), \mathrm{CuSO}_{4} \cdot 5 \mathrm{H}_{2} \mathrm{O}(0 \cdot 25), \mathrm{Na}_{2} \mathrm{MoO}_{4}(0 \cdot 25)$ and $\mathrm{MnSO}_{4} \cdot \mathrm{H}_{2} \mathrm{O}(0 \cdot 5)$ as described by Ford et al. (1958). Oxidative production of acid was determined for Larabinose, cellobiose, dextrin, D-galactose, D-glucose, glycerol, lactose, D-mannitol, D-mannose, melibiose, raffinose, L-rhamnose, salicin, D-sorbitol, sucrose and trehalose, while fermentative production of acid and gas was determined for D-glucose. API ZYM kits (BioMérieux) testing for butyrate esterase, myristate lipase, leucine arylamidase, cystine arylamidase, trypsinase, acid phosphatase, naphthol phosphohydrolase, $\alpha$-galactosidase, $\beta$-galactosidase, $\beta$-glucuronidase and acetyl $\beta$-glucosaminidase were used according to the manufacturer's instructions and read after incubation overnight at $22^{\circ} \mathrm{C}$. Susceptibility to antimicrobial agents was determined by the disc diffusion method using vibriostatic agent O/129 (2,4-diamino-6,7diisopropylpteridine) $(150 \mu \mathrm{g})$, sulphamethizol $(240 \mu \mathrm{g})$, ampicillin $(33 \mu \mathrm{g})$, penicillin $(5 \mu \mathrm{g})$, oxytetracycline $(80 \mu \mathrm{g})$ and oxolinic acid $(10 \mu \mathrm{g})$ (Neo-Sensitabs; Rosco). MüllerHinton agar (Difco) containing 2\% lysed horse blood was used for disc diffusion tests. The growth of Vibrio marinus was, however, inadequate on Müller-Hinton plates and BA was used for disc diffusion tests with this organism.

Numerical analysis. The statistical analysis was performed using SAS (versions 6.04 and 6.08) running under DOS and Windows on a 80386 PC. Uniformly positive or negative results were deleted from the data matrix. The similarity coefficients were calculated using simple matching $S_{\mathrm{ij}}=$ $C_{\mathrm{ij}} / C_{\mathrm{ij}}+D_{\mathrm{ij}}$, where $S_{\mathrm{ij}}$ is the similarity coefficient, $C_{\mathrm{ij}}$ is the concordant result and $D_{\mathrm{ij}}$ is the discordant result between strains $i$ and $j$. Clustering was done by unweighted mean linkage (Mardia et al., 1979). The hypothetical mean organism (HMO) was calculated the following way. In each cluster the test results were coded 0 (present) and 1 (not present). The most common value observed (the mode) was calculated for each character using all the individuals belonging to the specific cluster. Thus, if more than $50 \%$ of the individuals in a cluster had a character present, the mean individual for this cluster was set to present. This process was repeated for all the characters recorded giving a mean organism.

Ultrastructural studies. Cells grown in Luria broth (Miller, 1972) with $1.5 \% \mathrm{NaCl}$ for $48 \mathrm{~h}$ at $10{ }^{\circ} \mathrm{C}$ were both negatively stained with $1.5 \%$ phosphotungstic acid and photographed under a Philips model CM12 electron microscope $(80 \mathrm{kV})$ and under a JEOL model JSM 6400 scanning electron microscope $(10 \mathrm{kV})$. For SEM the cells were fixed in $2 \%$ glutaraldehyde in $0 \cdot 1 \mathrm{M}$ sodium cacodylate buffer and dried in a Balzers critical point dryer. Specimens for SEM were coated with $\mathrm{Au} / \mathrm{Pd}$ in a Polaron SEM coating unit E5000 $(1 \mathrm{kV} / 20 \mu \mathrm{A})$.

Western blotting. Antigen preparations used were either whole cells or Proteinase-K-treated cells. The cells were cultured in BHIB for $2 \mathrm{~d}$ at $15^{\circ} \mathrm{C}$, harvested and washed twice in PBS, pH 7·2. The concentration of bacteria was 
adjusted with PBS to $\mathrm{OD}_{520}=0 \cdot 3$, the solution then being divided in slants of $1.5 \mathrm{ml}$ in Eppendorf tubes. After centrifugation the supernatants were discarded and the pellets kept at $-22{ }^{\circ} \mathrm{C}$ until use. Before use in SDS-PAGE the pellet was solubilized in $150 \mu$ sample buffer $(1 \mathrm{ml} 0.5 \mathrm{M}$ Tris $/ \mathrm{HCl}, \mathrm{pH} 6.8,0.8 \mathrm{ml}$ glycerol, $1.6 \mathrm{ml} 10 \%$ SDS, $0.4 \mathrm{ml}$ $\beta$-mercaptoethanol, $0.2 \mathrm{ml} 0.2 \%$ bromophenol blue, $4.0 \mathrm{ml}$ distilled water) and then boiled for $5 \mathrm{~min}$ in a water bath. Cells were treated with Proteinase $\mathrm{K}$ after boiling. To each tube $10-15 \mu l$ Proteinase K $(0 \cdot 0025 \mathrm{~g}$ Proteinase $\mathrm{K}$ in $1 \mathrm{ml}$ $0.05 \mathrm{M}$ Tris $/ \mathrm{HCl}, \mathrm{pH} 8.6$ ) was added, the tubes being kept in a water bath for $1 \mathrm{~h}$ before use in SDS-PAGE. SDS-PAGE was performed in $4 \%$ stacking gel and $12 \%$ separating gel according to the method described by Laemmli (1970). Molecular mass markers, including Standard Low and Precoloured Standard markers (Bio-Rad) were run for each gel. Electrophoresis was performed at $200 \mathrm{~V}$ for $1 \mathrm{~h}$ (BioRad Protean R II Dual Slab Cell). The gels were either stained with $0 \cdot 2 \%$ Coomassie brilliant blue or transferred electrophoretically at $200 \mathrm{~V}$ for $1 \mathrm{~h}$ and immobilized onto $0.45 \mu \mathrm{m}$ reinforced nitrocellulose sheets (Schleicher \& Schuell) in a semi-dry system as described by KyhseAndersen (1984). The sheets were washed twice in PBS and non-specific binding was blocked by incubation with $1 \%$ BSA (A 9647; Sigma) for $1 \mathrm{~h}$ at room temperature, followed by three washings in PBS with $0.5 \%$ Tween (PBS-T). The membranes were incubated with two different polyclonal rabbit antisera (diluted 1:100 in PBS-T) overnight at $4{ }^{\circ} \mathrm{C}$. These antisera, designated antiserum 1 and antiserum 2 , had been raised against formalin-killed whole cells of strains $88 / 478^{\mathrm{T}}$ and $88 / 441^{\mathrm{T}}$, respectively (Lunder et al., 1995). The filters that had been incubated with serum were washed three times in PBS-T and incubated for $5 \mathrm{~h}$ at room temperature in peroxidase-labelled donkey anti-rabbit Ig (Amersham) diluted 1:2000 in PBS-T. The filters were then washed three times in PBS-T, once in PBS and rinsed once briefly in $0.05 \mathrm{M}$ sodium acetate, $\mathrm{pH} 5.0$. Finally the blots were developed in a substrate solution containing 3-amino-9ethyl-carbazole (AEC; Sigma) (40 mg AEC dissolved in $5 \mathrm{ml}$ $N, N$-dimethylformamide) in $0.05 \mathrm{M}$ sodium acetate, $\mathrm{pH} 5 \cdot 0$, and $\mathrm{H}_{2} \mathrm{O}_{2}$. The reaction was stopped by rinsing in tap water. The blots were read sufficiently using visual observation only.

Substrate gel electrophoresis. Substrate gel electrophoresis with gelatin as substrate was performed as described by Heussen \& Drowdle (1980) and modified by Rockey et al. (1988). Gelatin was copolymerized at $0.01 \%$ to a $12 \%$ polyacrylamide gel. To supernatants of BHIB shaking cultures, incubated for $3 \mathrm{~d}$, equal amounts of tracking dye, $5 \%$ SDS, $2 \%$ sucrose and $8 \mu \mathrm{g}$ phenol red $\mathrm{ml}^{-1}$ were added. After electrophoresis, the gels were washed with $2.5 \%$ Triton X-100 (Sigma) in water for $30 \mathrm{~min}$, incubated in $0.1 \mathrm{M}$ glycine/ $\mathrm{HCl}, \mathrm{pH} 8 \cdot 3$, for $2 \mathrm{~h}$ and stained with Coomassie brilliant blue.

Plasmid profiles. All strains of Vibrio sp. 1 and Vibrio sp. 2 were subjected to plasmid profiling. The bacteria were grown in shaking cultures using BHIB (Difco), with a final $\mathrm{NaCl}$ content of $2 \%$, and incubated at $15{ }^{\circ} \mathrm{C}$ for $24 \mathrm{~h}$. Plasmid isolation was performed by three different methods as described by Kado \& Liu (1981), He et al. (1990) and a rapid small-scale modification of the alkaline lysis technique of Birnboim \& Doly (1979) as described by Maniatis et al. (1982).

Agarose gel electrophoresis was performed in $1 \%$ agarose gels with Tris/borate/EDTA buffer $(89 \mathrm{mM}$ Tris, $89 \mathrm{mM}$ boric acid, 2.5 mM EDTA, $\mathrm{pH} 8 \cdot 0$ ) at $120 \mathrm{~V}$ for $3 \mathrm{~h}$ at room temperature in a vertical gel apparatus. The agarose gels were stained in ethidium bromide and destained in distilled water before photographs of the gels were taken under UV light. Escherichia coli V517 (Macrina et al., 1978) with plasmids of eight different sizes and E. coli K-12 strains containing plasmids pDK9 and S-a (Bukhari et al., 1977), respectively, were used as standards.

Plasmid DNA from 15 selected Vibrio sp. 1 strains and nine selected Vibrio sp. 2 strains were subjected to digestion with HindIII (Life Technologies). The digests were electrophoresed in a $0.7 \%$ agarose gel in a horizontal gel apparatus. $\lambda$ DNA/HindIII fragments and $\Phi$ X174RF DNA/HaeIII fragments (Pharmacia) were used as standards.

Total DNA isolation and purification. Isolation and purification of total bacterial DNA for colony hybridization and for restriction endonuclease digestion were carried out as described by Hull et al. (1981). Bacterial cells were harvested from 0.51 BHIB broth cultures containing $2 \% \mathrm{NaCl}$, incubated with shaking for $2 \mathrm{~d}$ at $15^{\circ} \mathrm{C}$.

The cells were resuspended in a solution of $2 \mathrm{ml} 25 \%$ sucrose, $1 \mathrm{M}$ Tris, 0.5 M EDTA, $\mathrm{pH} 8.0$, and lysed with lysozyme (Sigma). To this solution were added $0.1 \mathrm{mg}$ Proteinase K (Sigma), $400 \mu 10.5$ M EDTA and $250 \mu 110 \%$ $N$-lauroylsarcosine. The solution was then kept at $0^{\circ} \mathrm{C}$ for $10 \mathrm{~min}$ and at $50{ }^{\circ} \mathrm{C}$ for $18 \mathrm{~h}$. DNA was purified in a $\mathrm{CsCl}$ gradient containing PMSF. The DNA was dialysed in TE buffer, $\mathrm{pH} 8 \cdot 0$.

Colony hybridization. All the strains listed in Table 1, including type strains of genus Vibrio, except the type strains for Vibrio anguillarum, Vibrio cholerae, Vibrio costicola, Vibrio gazogenes, Vibrio mytili, Vibrio navarrensis, Vibrio nigripulchritudo and Vibrio vulnificus, were inoculated onto nitrocellulose membranes (Schleicher \& Schuell) placed on the surface of blood agar plates with a final $\mathrm{NaCl}$ content of $2 \%$ and incubated at $15{ }^{\circ} \mathrm{C}$ overnight. The membranes were then soaked in $10 \%$ SDS for $3 \mathrm{~min}$, denatured in $0.5 \mathrm{M}$ $\mathrm{NaOH}$ for $5 \mathrm{~min}$ and neutralized in $1.5 \mathrm{M} \mathrm{NaCl}$ and $0.5 \mathrm{M}$ Tris $/ \mathrm{HCl}$ twice for $5 \mathrm{~min}$. The membranes were then airdried and baked under vacuum at $80^{\circ} \mathrm{C}$ for $2 \mathrm{~h}$ and deproteinated at $68{ }^{\circ} \mathrm{C}$ for $1 \mathrm{~h}$ in a solution of $2 \times \operatorname{SSC}(1 \times$ $\mathrm{SSC}=0 \cdot 15 \mathrm{M} \mathrm{NaCl}$ and $0 \cdot 015 \mathrm{M}$ sodium citrate), $0 \cdot 1 \%$ SDS and $100 \mathrm{mg}$ Proteinase $\mathrm{K} \mathrm{ml}^{-1}$ (Maniatis et al., 1982). Total bacterial DNAs from Vibrio sp. 1 strains $88 / 478^{\mathrm{T}}$ and $90 / 4271-1 \mathrm{~b}$ and Vibrio sp. 2 strains $88 / 441^{\mathrm{T}}$ and $90 / 4271-3 \mathrm{a}$ were used as probes. The DNAs were digested with HaeIII (Life Technologies), $1 \mu \mathrm{g}$ being labelled with digoxigenin-11dUTP using random-primed labelling (Boehringer Mannheim) in accordance with the manufacturer's instructions.

Hybridization and immunological detection with alkaline phosphatase-conjugated antibodies against digoxigenin were performed as recommended by the manufacturer (Boehringer Mannheim). Prehybridization and hybridization were performed at $68^{\circ} \mathrm{C}$ (selected after initial comparison of various temperatures) in $5 \times \mathrm{SSC}, 0.1 \% \mathrm{~N}$ lauroylsarcosine, $0.02 \%$ SDS and $1 \%$ blocking reagent, a purified fraction of dry milk powder (Boehringer Mannheim). The membranes were then washed twice with $2 \times \mathrm{SSC}$ and $0 \cdot 1 \% \mathrm{SDS}$ at room temperature and twice with $0 \cdot 1 \times$ SSC and $0 \cdot 1 \%$ SDS at $68^{\circ} \mathrm{C}$ for $1 \mathrm{~h}$. The blots were allowed to develop with 4-nitro blue tetrazolium chloride and 5-bromo-4-chloro-3-indolyl phosphate for 15-60 min. Two identical membranes were always assayed in parallel. 
Table 1. Reference strains, type strains and new isolates used in this study

\begin{tabular}{|c|c|}
\hline Species & Strain* \\
\hline Aeromonas salmonicida & ATCC 14174 (NCMB 833) \\
\hline 'Vibrio abalonicus' (Pienta \& Tang, 1996) & ATCC 27390 \\
\hline 'Vibrio adaptus' (Sneath \& Skerman, 1966) & ATCC 19263 (NCMB 1052) \\
\hline Vibrio aestuarianus & ATCC $35048^{\mathrm{T}}\left(\mathrm{NCMB} 2236^{\mathrm{T}}\right)$ \\
\hline Vibrio alginolyticus & ATCC $17749^{\mathrm{T}}\left(\mathrm{NCMB} 1903^{\mathrm{T}}\right)$ \\
\hline 'Vibrio algosus' (ZoBell \& Upham, 1944) & ATCC 14390 (NCMB 2073) \\
\hline Vibrio anguillarum & ATCC $19264^{\mathrm{T}}\left(\mathrm{NCMB} 6^{\mathrm{T}}\right) ;$ ATCC 14181 (NCMB 829) \\
\hline Vibrio campbellii & ATCC $25920^{\mathrm{T}}$ \\
\hline Vibrio carchariae & ATCC $35084^{\mathrm{T}}$ \\
\hline Vibrio cholerae & ATCC $14035^{\mathrm{T}}\left(\mathrm{NCTC} 8021^{\mathrm{T}}\right)$; NVI Ft 863 \\
\hline Vibrio cincinnatiensis & ATCC $35912^{\mathrm{T}}\left(\mathrm{NCTC} 12012^{\mathrm{T}}\right)$ \\
\hline Vibrio costicola & ATCC $33508^{\mathrm{T}}\left(\mathrm{NCMB} 701^{\mathrm{T}}\right)$ \\
\hline 'Vibrio cuneatus' (Davis \& Park, 1962) & ATCC 6972 \\
\hline 'Vibrio cyclosites' (Lessel, 1962) & ATCC 14635 (NCIB 2581) \\
\hline Vibrio damsela (Photobacterium damselae subsp. damselae) & ATCC $33539^{\mathrm{T}}\left(\mathrm{NCMB} 2184^{\mathrm{T}}, \mathrm{CDC} 2588-80^{\mathrm{T}}\right)$ \\
\hline Vibrio diazotrophicus & ATCC $33466^{\mathrm{T}}\left(\mathrm{NCMB} 2169^{\mathrm{T}}\right)$ \\
\hline Vibrio fischeri & ATCC $7744^{\mathrm{T}}\left(\mathrm{NCMB} 1281^{\mathrm{T}}\right)$ \\
\hline Vibrio fluvialis & ATCC $33809^{\mathrm{T}}\left(\mathrm{NCMB} 2249^{\mathrm{T}}, \mathrm{NCTC} 11327^{\mathrm{T}}\right)$ \\
\hline Vibrio furnissii & $\operatorname{ATCC} 35016^{\mathrm{T}}\left(\mathrm{CDC} \mathrm{B} 3215^{\mathrm{T}}\right)$ \\
\hline Vibrio gazogenes & ATCC $29988^{\mathrm{T}}$ \\
\hline Vibrio harveyi & ATCC $14126^{\mathrm{T}}\left(\mathrm{NCMB} 1280^{\mathrm{T}}\right)$ \\
\hline Vibrio hollisae & ATCC $33564^{\mathrm{T}}$ \\
\hline 'Vibrio hyperoptica' (Baumann et al., 1971) & CDC 9100-79 \\
\hline Vibrio ichthyoenteri & ATCC $700023^{\mathrm{T}}\left(\right.$ IFO $\left.15847^{\mathrm{T}}\right)$ \\
\hline Vibrio iliopiscarius (Photobacterium iliopiscarium) & ATCC $51760^{\mathrm{T}}$ \\
\hline Vibrio logei & ATCC $29985^{\mathrm{T}} ;$ ATCC $15382(\mathrm{NCMB} 1143)$ \\
\hline 'Vibrio marinofulvus' (ZoBell \& Upham, 1944) & ATCC 14395 (NCMB 2076) \\
\hline Vibrio marinus (Moritella marina) & ATCC $15381^{\mathrm{T}}\left(\mathrm{NCMB} 1144^{\mathrm{T}}\right)$ \\
\hline Vibrio mediterranei & ATCC $43341^{\mathrm{T}}\left(\mathrm{CECT} 621, \mathrm{NCTC} 11946^{\mathrm{T}}\right)$ \\
\hline Vibrio metschnikovii & NCTC $8443^{\mathrm{T}}\left(\right.$ ATCC $\left.7708^{\mathrm{T}}\right)$ \\
\hline Vibrio mimicus & $\operatorname{ATCC} 33653^{\mathrm{T}}\left(\mathrm{CDC} 1721-77^{\mathrm{T}}\right)$ \\
\hline Vibrio mytili & CECT $632^{\mathrm{T}}$ \\
\hline Vibrio natriegens & ATCC $14048^{\mathrm{T}}$ \\
\hline Vibrio navarrensis & CIP $103381^{\mathrm{T}}$ \\
\hline 'Vibrio neocistes' (Lessel, 1962) & ATCC 14636 (NCIB 2582) \\
\hline 'Vibrio neptuna' (Baumann et al., 1971) & CDC $9102-79$ \\
\hline Vibrio nereis & ATCC $25917^{\mathrm{T}}\left(\mathrm{NCMB} 1897^{\mathrm{T}}\right)$ \\
\hline Vibrio nigripulchritudo & ATCC $27043^{\mathrm{T}}$ \\
\hline Vibrio ordalii & ATCC $33509^{\mathrm{T}}\left(\mathrm{NCMB} 2167^{\mathrm{T}}\right)$ \\
\hline Vibrio orientalis & ATCC $33934^{\mathrm{T}}\left(\mathrm{NCMB} 2195^{\mathrm{T}}\right)$ \\
\hline Vibrio parahaemolyticus & $\operatorname{ATCC} 17802^{\mathrm{T}}\left(\mathrm{EB} 101^{\mathrm{T}}\right)$ \\
\hline Vibrio pelagius I (Listonella pelagia) & ATCC $25916^{\mathrm{T}}\left(\mathrm{NCMB} 1900^{\mathrm{T}}\right)$ \\
\hline Vibrio pelagius II (Listonella pelagia) & NCMB 2253 \\
\hline Vibrio penaeicida & ATCC 51842 \\
\hline Vibrio proteolyticus & ATCC $15338^{\mathrm{T}}\left(\mathrm{NCMB} 1326^{\mathrm{T}}\right)$ \\
\hline 'Vibrio psychroerythrus' (D’Aoust \& Kushner, 1972) & ATCC 27364 (NRC 1004) \\
\hline Vibrio salmonicida & $\begin{array}{l}\text { ATCC } 43839^{\mathrm{T}}\left(\mathrm{NCMB} 2262^{\mathrm{T}}\right) \text {; NCMB } 2245 ; \\
\text { NVI } 90 / 1667-10 \mathrm{c} \text { (isolated from fish farm 'e') } \dagger\end{array}$ \\
\hline Vibrio scophthalmi & CECT $4638^{\mathrm{T}}$ \\
\hline Vibrio splendidus I & ATCC $33125^{\mathrm{T}}\left(\mathrm{NCMB} 1^{\mathrm{T}}\right)$ \\
\hline Vibrio splendidus II & NCMB 2251 \\
\hline Vibrio tubiashii & ATCC $19109^{\mathrm{T}}\left(\mathrm{NCMB} 1340^{\mathrm{T}}\right)$ \\
\hline 'Vibrio tyrosinaticus' (Sneath \& Skerman, 1966) & ATCC 19378 (NCIB 9045) \\
\hline Vibrio vulnificus & ATCC $27562^{\mathrm{T}} ;$ ATCC $33147(\mathrm{ES}-7601)$ \\
\hline Yersinia ruckeri & ATCC $29473^{\mathrm{T}}\left(\right.$ CDC $\left.2396-61^{\mathrm{T}}\right)$ \\
\hline
\end{tabular}


Vibrio viscosus sp. nov. and Vibrio wodanis sp. nov.

Table 1 (cont.)

\begin{tabular}{|c|c|c|c|}
\hline New isolate $\dagger$ & Fish farm origin & New isolate $\dagger$ & Fish farm origin \\
\hline Vibrio sp. $188 / 478^{\mathrm{T}}$ & $\mathrm{a}$ & Vibrio sp. 2 90/551-2 & $\mathrm{t}$ \\
\hline Vibrio sp. $189 / 1407-1 b$ & $\mathrm{f}$ & Vibrio sp. 2 90/685-1 & $\mathrm{m}$ \\
\hline Vibrio sp. $189 / 1902$ & $\mathrm{~b}$ & Vibrio sp. $290 / 685-2$ & $\mathrm{~m}$ \\
\hline Vibrio sp. $189 / 2067$ & $\mathrm{i}$ & Vibrio sp. $290 / 685-3$ & $\mathrm{~m}$ \\
\hline Vibrio sp. $189 / 2148 \S$ & $\mathrm{h}$ & Vibrio sp. 2 90/765-1 & o \\
\hline Vibrio sp. $190 / 793-1$ & $\mathrm{c}$ & Vibrio sp. $290 / 765-2$ & $\mathrm{o}$ \\
\hline Vibrio sp. 1 90/793-2 & $\mathrm{c}$ & Vibrio sp. 2 90/1027-2a & $\mathrm{j}$ \\
\hline Vibrio sp. $190 / 793-3$ & $\mathrm{c}$ & Vibrio sp. 2 90/1027-4a & $\mathrm{j}$ \\
\hline Vibrio sp. $190 / 1027-3 b$ & $\mathrm{j}$ & Vibrio sp. 2 90/1027-6 & $\mathrm{j}$ \\
\hline Vibrio sp. 1 90/1097-1 & $\mathrm{c}$ & Vibrio sp. 2 90/1027-8 & $\mathrm{j}$ \\
\hline Vibrio sp. $190 / 1097-2$ & $\mathrm{c}$ & Vibrio sp. 2 90/1162-10 & $\mathrm{d}$ \\
\hline Vibrio sp. $190 / 1097-3$ & $\mathrm{c}$ & Vibrio sp. 2 90/1162-12 & $\mathrm{d}$ \\
\hline Vibrio sp. $190 / 1162-10$ & $\mathrm{~d}$ & Vibrio sp. 2 90/1207-11 & $\mathrm{k}$ \\
\hline Vibrio sp. $190 / 1207-16 b$ & $\mathrm{k}$ & Vibrio sp. 2 90/1207-14 & $\mathrm{k}$ \\
\hline Vibrio sp. 1 90/1667-12 & e & Vibrio sp. 2 90/1207-16a & $\mathrm{k}$ \\
\hline Vibrio sp. $190 / 1667-14$ & $\mathrm{e}$ & Vibrio sp. $290 / 1667-13$ & e \\
\hline Vibrio sp. $190 / 4271-1 b$ & $\mathrm{~g}$ & Vibrio sp. 2 90/1667-21 & $\mathrm{e}$ \\
\hline Vibrio sp. $190 / 4271-2 b$ & g & Vibrio sp. 2 90/2024-1 & $\mathrm{r}$ \\
\hline Vibrio sp. $190 / 4271-3 b$ & $\mathrm{~g}$ & Vibrio sp. $290 / 2024-2$ & $\mathrm{r}$ \\
\hline Vibrio sp. $190 / 4271-5 b$ & $\mathrm{~g}$ & Vibrio sp. $290 / 2024-3$ & $\mathrm{r}$ \\
\hline Vibrio sp. $288 / 441^{\mathrm{T}}$ & $\mathrm{q}$ & Vibrio sp. $290 / 2024-4$ & $\mathrm{r}$ \\
\hline Vibrio sp. $289 / 11$ & $\mathrm{p}$ & Vibrio sp. $290 / 2024-5$ & $\mathrm{r}$ \\
\hline Vibrio sp. $289 / 1829$ & s & Vibrio sp. $290 / 2024-6$ & $\mathrm{r}$ \\
\hline Vibrio sp. $289 / 5532$ & $\mathrm{n}$ & Vibrio sp. $290 / 2024-7$ & $\mathrm{r}$ \\
\hline Vibrio sp. 2 90/325-1 & 1 & Vibrio sp. $290 / 2024-8$ & $\mathrm{r}$ \\
\hline Vibrio sp. 2 90/325-2 & 1 & Vibrio sp. 2 90/4271-2a & g \\
\hline Vibrio sp. 2 90/325-3 & 1 & Vibrio sp. 2 90/4271-3a & $\mathrm{g}$ \\
\hline Vibrio sp. 2 90/551-1 & $\mathrm{t}$ & & \\
\hline
\end{tabular}

* ATCC, American Type Culture Collection, Manassas, VA, USA; CDC, Centers for Disease Control and Prevention, Atlanta, GA, USA; CECT, Coleccion Espanola de Cultivos Tipo, Valencia, Spain; CIP, Collection of the Institut Pasteur, Paris, France; IFO, Institute for Fermentation Osaka, Osaka, Japan; NCMB, National Collection of Marine Bacteria, Aberdeen, UK; NCTC, National Collection of Type Cultures, London, UK; NVI, National Veterinary Institute, Oslo, Norway.

$\dagger$ NVI bacterial stock collection at the National Veterinary Institute, Oslo, Norway. All strains studied from this collection originate from Norway. The first two digits from left indicate the year of isolation. The next three or four digits after the slash represent the journal number and the digit after the hyphen represents isolates from different fish in the same farm isolated during the same disease outbreak. Lower-case letters to the right in the designation after the hyphen indicate different isolates from the same fish.

\$ Lower-case letters indicate different farms with Atlantic salmon in net pens located along the coast of Norway, except farms ' $\mathrm{g}$ ' and ' $\mathrm{k}$ ' which are land-located with an intake of sea water from depths of 50-60 m.

$\S$ Isolated from a plaice (Pleuronectes platessa) which was a wild-capture stock fish kept in net pens for 5 months before development of winter ulcer.

Agarose gel electrophoresis of restriction-endonucleasedigested total DNA. Based on results from phenotypical characterization and colony hybridization, total DNA from eight Vibrio isolates from Atlantic salmon with winter ulcer and 14 reference strains of the genus Vibrio (strains listed as target strains in Table 7) were selected for restriction endonuclease digestion and electrophoresis. Aeromonas salmonicida subsp. salmonicida and Yersinia ruckeri were included as controls.

Total DNA $(4 \mu \mathrm{g})$ of each isolate was digested with HaeIII or HindIII (the enzymes were selected after initial comparison of various enzymes) before electrophoresis in a $0.7 \%$ agarose gel. DNA was stained with ethidium bromide and photographed under UV light.
Southern hybridization. HindIII-digested DNAs from agarose gels were transferred to GeneScreen nylon membranes (DuPont) by Southern blotting (Southern, 1975). The nylon membranes were air-dried and the DNA was fixed to the membranes by UV light. HindIII-digested total DNAs from the strains listed in Table 7 were used as probes. Probe DNA was labelled with digoxigenin-11-dUTP (Boehringer Mannheim) according to the instructions of the respective manufacturers. Detection with 3-(2'-spiroadamantane)-4methoxy-4-(3"-phosphoryloxy)-phenyl-1,2-dioethane (AMPPD) and luminescence following hybridization with digoxigenin-labelled probe DNA were performed as recommended by the manufacturer (Boehringer Mannheim). Prehybridization and hybridization were performed at $42^{\circ} \mathrm{C}$ 
Table 2. Physiological and biochemical characterization of 20 strains of Vibrio sp. 1, 35 strains of Vibrio sp. 2, one strain of $V$. salmonicida isolated from Atlantic salmon with winter ulcer, and 16 type and reference strains of Vibrio

1, Vibrio sp. 1; 2, Vibrio sp. 2; 3, V. marinus NCMB $1144^{\mathrm{T}} ; 4$, V. ordalii $\mathrm{NCMB} 2167^{\mathrm{T}} ; 5$, V. logei ATCC 15382; 6, V. logei NCMB 1143; 7, V. logei ATCC 29985 ${ }^{\mathrm{T}} ; 8, V$. salmonicida NCMB 2262 $;$ 9, V. salmonicida NCMB 2245; 10, V. salmonicida 90/1667-10c (isolated from Atlantic salmon with winter ulcer); 11, V. pelagius I NCMB 1900 ${ }^{\mathrm{T}} ; 12$, V. pelagius II NCMB 2253;13, $V$. splendidus I NCMB $1^{\mathrm{T}} ; 14, V$. splendidus II NCMB 2251; 15, V. damsela NCMB 2184 ; 16, V. anguillarum ATCC 14181; 17 , V. orientalis NCMB $2195^{\mathrm{T}} ; 18$, V. tubiashii NCMB $1340^{\mathrm{T}} ; 19,$. . fischeri NCMB $1281^{\mathrm{T}}$. +, All strains positive; -, all strains negative. Numerical values indicate percentage positive strains. All strains were positive for catalase, oxidase, motility, growth at $15^{\circ} \mathrm{C}$, growth in $1,2,3$ and $4 \% \mathrm{NaCl}$, susceptibility to vibriostatic agent, oxytetracycline and oxolinic acid, fermentation of Dglucose, oxidative production of acid from D-galactose and D-glucose, production of alkaline phosphatase and caprylate esterase. All strains were negative for Gram stain, production of ornithine decarboxylase, oxidative production of acid from inositol, Dxylose, production of chymotrypsinase, $\alpha$-glucosidase, $\beta$-glucosidase, $\alpha$-mannosidase and $\alpha$-fucosidase.

\begin{tabular}{|c|c|c|c|c|c|c|c|c|c|c|c|c|c|c|c|c|c|c|c|}
\hline Character & 1 & 2 & 3 & 4 & 5 & 6 & 7 & 8 & 9 & 10 & 11 & 12 & 13 & 14 & 15 & 16 & 17 & 18 & 19 \\
\hline \multicolumn{20}{|l|}{ Colony colour: } \\
\hline White & - & - & - & - & - & - & - & - & - & - & - & + & + & + & - & - & + & + & - \\
\hline Yellow & - & + & - & - & + & + & + & - & - & - & - & - & - & - & - & - & - & - & - \\
\hline Grey & + & - & + & + & - & - & - & + & + & + & + & - & - & + & + & + & - & + & + \\
\hline Green & - & - & - & - & - & - & - & - & - & - & - & - & - & - & - & + & - & - & - \\
\hline \multicolumn{20}{|l|}{ Colony opacity: } \\
\hline Translucent & + & - & + & + & - & - & - & + & + & + & + & - & - & - & + & - & - & - & + \\
\hline Opaque & - & + & - & - & + & + & + & - & - & - & - & + & + & + & - & + & + & + & - \\
\hline \multicolumn{20}{|l|}{ Degradation of: } \\
\hline Starch & 95 & + & - & - & - & - & - & - & - & - & - & + & + & + & - & + & + & + & - \\
\hline Alginate & - & 23 & - & - & - & - & - & - & - & - & - & + & + & - & - & - & - & - & - \\
\hline Gelatin & + & + & + & + & - & - & - & - & - & - & - & + & + & + & - & + & + & + & - \\
\hline Casein & + & - & - & + & - & - & - & - & - & - & - & - & + & - & - & + & + & + & + \\
\hline DNA & + & 89 & - & + & + & + & + & + & + & + & + & - & - & + & + & + & + & + & + \\
\hline Tween 80 & + & + & + & - & + & + & + & - & - & - & + & + & + & + & - & + & + & + & - \\
\hline Lecithin & + & 3 & + & + & + & + & + & - & - & - & + & - & + & + & - & + & + & + & + \\
\hline Urea & + & 20 & + & - & + & + & - & - & - & - & - & - & - & - & + & - & - & - & - \\
\hline Aesculin & - & 3 & + & - & + & + & + & - & - & - & + & - & + & - & - & - & - & - & + \\
\hline Haemolysis of bovine erythrocytes & + & 94 & + & + & - & - & - & - & - & - & - & - & + & + & + & + & - & + & + \\
\hline Luminescence & - & - & - & - & - & - & + & - & - & - & - & - & + & - & - & - & + & - & - \\
\hline Methyl red test & 5 & + & - & - & + & - & + & - & - & - & - & + & + & + & + & - & + & + & - \\
\hline Voges-Proskauer & - & - & - & - & - & - & - & - & - & - & - & - & - & - & + & + & - & - & + \\
\hline \multicolumn{20}{|l|}{ Production of: } \\
\hline Gas from $0.7 \%$ glucose & - & - & - & - & - & - & - & - & - & - & - & - & - & - & + & - & - & - & - \\
\hline Arginine dihydrolase & - & - & - & - & - & - & - & - & - & - & - & - & + & - & + & + & + & + & - \\
\hline Lysine decarboxylase & + & - & - & - & - & + & + & - & - & - & - & - & - & - & - & - & - & - & + \\
\hline Indole & - & 89 & - & - & - & - & - & - & - & - & - & + & + & + & - & - & + & + & - \\
\hline \multicolumn{20}{|l|}{ Susceptibility to: } \\
\hline Ampicillin & + & + & + & + & + & + & + & + & + & + & + & + & - & - & + & - & + & + & + \\
\hline Penicillin & + & - & - & - & - & - & - & - & - & - & - & + & - & - & - & - & - & + & - \\
\hline Sulphamethizol & + & + & + & + & + & + & + & + & + & + & - & + & + & - & + & - & - & + & + \\
\hline \multicolumn{20}{|l|}{ Oxidative production of acid from: } \\
\hline $0.7 \%$ L-Arabinose & - & - & - & - & - & - & - & - & - & - & + & - & - & - & - & - & - & - & - \\
\hline $0.7 \%$ Cellobiose & - & - & - & - & + & + & + & - & - & - & - & - & + & + & - & - & + & + & - \\
\hline $0.7 \%$ Dextrin & + & + & - & - & + & + & + & - & - & - & + & + & + & + & + & - & + & + & - \\
\hline $0.7 \%$ Glycerol & - & 94 & + & - & + & + & + & + & + & + & + & + & + & + & + & + & - & + & - \\
\hline $0.7 \%$ Lactose & - & - & - & - & + & + & - & - & - & - & - & - & - & - & - & - & - & - & - \\
\hline $0 \cdot 7 \%$ D-Mannitol & - & 34 & - & + & - & - & + & + & + & + & + & + & + & + & - & + & + & + & + \\
\hline $0.7 \%$ D-Mannose & - & + & + & - & + & + & + & + & + & + & + & + & + & - & + & + & + & + & - \\
\hline $0.7 \%$ Melibiose & - & - & - & - & - & - & - & - & - & - & + & - & + & - & - & - & - & + & - \\
\hline $0.7 \%$ Raffinose & - & - & - & - & - & - & - & - & - & - & + & - & - & - & - & - & - & - & - \\
\hline $0.7 \%$ L-Rhamnose & - & - & - & - & - & - & - & - & - & - & + & - & - & - & - & - & - & - & - \\
\hline
\end{tabular}


Vibrio viscosus sp. nov. and Vibrio wodanis sp. nov.

Table 2 (cont.)

\begin{tabular}{|c|c|c|c|c|c|c|c|c|c|c|c|c|c|c|c|c|c|c|c|}
\hline Character & 1 & 2 & 3 & 4 & 5 & 6 & 7 & 8 & 9 & 10 & 11 & 12 & 13 & 14 & 15 & 16 & 17 & 18 & 19 \\
\hline $0.7 \%$ Salicin & - & - & - & - & - & + & - & - & - & - & + & - & - & - & - & - & - & - & + \\
\hline $0.7 \%$ D-Sorbitol & - & 6 & - & - & - & - & - & - & - & - & - & - & - & - & - & + & - & - & - \\
\hline $0.7 \%$ Sucrose & - & 83 & - & + & + & + & - & - & - & - & + & + & - & - & - & + & + & + & + \\
\hline $0.7 \%$ Trehalose & - & + & - & - & + & + & + & + & + & + & + & + & + & + & - & + & + & + & - \\
\hline \multicolumn{20}{|l|}{ Growth in $\mathrm{NaCl}$ : } \\
\hline $0.5 \%$ & - & 97 & - & + & + & + & + & + & + & + & + & + & + & + & + & + & + & + & + \\
\hline $5 \%$ & - & 97 & + & + & + & + & + & + & + & + & + & + & + & + & + & + & + & + & + \\
\hline $7 \%$ & - & 60 & - & + & - & - & - & - & - & - & + & + & - & + & - & + & + & + & + \\
\hline \multicolumn{20}{|l|}{ Growth at: } \\
\hline $4^{\circ} \mathrm{C}$ & + & + & + & + & + & + & + & + & + & + & + & - & + & + & - & - & + & - & - \\
\hline $10^{\circ} \mathrm{C}$ & + & + & + & + & + & + & + & + & + & + & + & + & + & + & + & + & + & + & + \\
\hline $22{ }^{\circ} \mathrm{C}$ & + & 91 & + & + & + & + & + & - & - & - & + & + & + & + & + & + & + & + & + \\
\hline $25^{\circ} \mathrm{C}$ & + & 83 & - & + & + & + & - & - & - & - & + & + & + & + & + & + & + & + & + \\
\hline $30^{\circ} \mathrm{C}$ & - & - & - & + & - & + & - & - & - & - & + & + & + & + & + & + & + & + & + \\
\hline \multicolumn{20}{|l|}{ API ZYM tests: } \\
\hline Butyrate esterase & + & 83 & + & + & + & + & + & + & - & + & + & + & + & + & + & + & + & + & - \\
\hline Myristate lipase & + & 3 & - & - & - & - & - & - & - & - & - & - & + & - & - & - & + & - & - \\
\hline Leucine arylamidase & + & + & + & + & + & + & + & - & - & - & - & + & + & + & + & + & + & + & + \\
\hline Valine arylamidase & 5 & 86 & - & - & - & - & - & - & - & - & - & - & - & + & - & + & + & + & - \\
\hline Cystine arylamidase & - & - & - & - & - & - & - & - & - & - & - & - & - & - & - & + & - & + & - \\
\hline Trypsinase & - & - & - & - & - & - & - & - & - & - & - & + & + & + & - & - & - & - & - \\
\hline Acid phosphatase & + & 69 & + & + & + & + & + & + & + & + & + & + & + & + & + & + & + & - & + \\
\hline Naphthol phosphohydrolase & + & 97 & + & + & + & + & + & + & + & + & + & + & + & + & + & + & + & + & + \\
\hline$\alpha$-Galactosidase & - & - & - & - & - & + & - & - & - & - & - & - & - & - & - & - & - & - & - \\
\hline$\beta$-Galactosidase & - & - & - & - & - & + & - & - & - & - & - & - & - & - & - & - & - & - & - \\
\hline$\beta$-Glucuronidase & - & - & - & - & - & - & - & - & - & - & - & - & - & - & - & - & - & - & - \\
\hline Acetyl $\beta$-glucosaminidase & - & 77 & - & + & - & - & - & - & - & - & - & - & + & - & + & + & + & + & + \\
\hline
\end{tabular}

in $50 \%$ formamide, $5 \times \mathrm{SSC}, 0 \cdot 1 \% N$-lauroylsarcosine, $0.02 \%$ SDS and $2 \%$ blocking reagent. The membranes were then washed in $5 \times \mathrm{SSC}$ and $0.1 \% \mathrm{SDS}$ at $65^{\circ} \mathrm{C}$. Luminescence was detected after exposure of X-ray films (Kodak XRP) to the membranes for $15 \mathrm{~min}-12 \mathrm{~h}$. The membranes were washed in distilled water and the labelled DNA was eluted from the filters in $0.2 \mathrm{M}$ sodium hydroxide and $0 \cdot 1 \%$ SDS at $37^{\circ} \mathrm{C}$.

Hybridization by the hydroxyapatite method. Strains were grown on BHIA plates with a final $\mathrm{NaCl}$ content of $2 \%$. Lysis of cells with subsequent purification of DNA and DNA hybridization assays using hydroxyapatite were carried out as described previously (Brenner et al., 1982). DNAs from Vibrio sp. 1 strain $88 / 478^{\mathrm{T}}$ and Vibrio sp. 2 strain $88 / 441^{\mathrm{T}}$ were labelled with ${ }^{32} \mathrm{P}$ by the nick-translation method using a commercial system (Life Technologies).

Determination of $\mathbf{G}+\mathbf{C}$ content. The $\mathrm{G}+\mathrm{C}$ content $(\mathrm{mol} \%)$ was determined for DNAs from Vibrio sp. 1 strain $88 / 478^{\mathrm{T}}$ and Vibrio sp. 2 strain $88 / 441^{\mathrm{T}}$ by the thermal denaturation method (Mandel et al., 1970).

16S rDNA sequencing. Two primers, V1 [5'-AGAGTTTGATCATGGCTCAGA-3'; positions 8-28 (E. coli $16 \mathrm{~S}$ rRNA numbering)] and V3 (5'-GGTTACCTTGTTACGACTTC$3^{\prime} ; 1509-1490$ ) were used for amplification of the 16S rRNA gene of Vibrio sp. 1 (Phenon 1) $88 / 478^{\mathrm{T}}$ and Vibrio sp. 2 (Phenon 2) $88 / 441^{\mathrm{T}}$. Total DNA $(5 \mu \mathrm{l})$ was added to $45 \mu \mathrm{l}$ of a mix of PCR reagents containing $1 \times$ PCR buffer $(\mathrm{F}-511$ for Dynazyme DNA polymerase; Finnzymes) with 0.7 units of Taq polymerase (F-501L Dynazyme DNA polymerase; Finnzymes), 10 pmol each primer and $200 \mu \mathrm{M}$ each dNTP (F-560L dNTP mix; Finnzymes). PCR was performed in a thermal cycler and the temperature profile was: denaturation at $95^{\circ} \mathrm{C}$ for $60 \mathrm{~s}$, then 30 cycles at $95^{\circ} \mathrm{C}$ for $60 \mathrm{~s}, 60^{\circ} \mathrm{C}$ for $30 \mathrm{~s}$ and $72^{\circ} \mathrm{C}$ for $60 \mathrm{~s}$. The PCR products were purified on a Centricon-100 (Perkin Elmer) column and directly sequenced on a Perkin Elmer ABI Prism 377 automatic sequencer in both directions by using the ABI Prism BigDye Terminator Cycle Sequencing Ready Reaction Kit with AmpliTaq DNA polymerase (Perkin Elmer). In addition to primers V1 and V3, forward primers V5 (5'-GTCCACACTCCTACGGGAGGC-3'; 331-351), 538C (5'-GTAGTCCACGCCGTAAACG-3'; 799-817) (Pettersson et al., 1996) and V6 (5'-GGGGAYGACGTCAAGTC-3'; 1183-1199), and reverse primers 3 (5'-ACTGCTGCCTCCCGT-3'; 357343) (Dewhirst et al., 1992), 5 (5'-CTACCAGGGTATCTAATC-3'; 802-785) (Dewhirst et al., 1992) and V4 (5'GTTTATCACCGGCAGTCTC-3', 1171-1153) were used. Primers V1 and V3-V6 were designed in this study. Nucleotide sequences were analysed using the GCG Sequence Analysis Software Package (version 8) from the Genetics Computer Group (Madison, WI, USA).

16S rDNA analysis. The 16S rDNA sequences of the two test strains were aligned using CLUSTAL W software (Thompson 
et al., 1994). The phylogenetic tree was constructed by the neighbour-joining method (Saitou \& Nei, 1987). Bootstrap confidence values were obtained with 1000 resamplings.

\section{RESULTS}

\section{Physiological and biochemical characterization}

All the strains isolated from winter ulcers were facultative anaerobic, Gram-negative rods, which were susceptible to vibriostatic agent, growing only in media supplemented with $\mathrm{NaCl}$. The optimum temperature for growth was below $30^{\circ} \mathrm{C}$. The results from physiological and biochemical characterization are listed in Table 2. Sixty characters were used to calculate the similarity coefficients based on numerical taxonomy, while a further 25 characters were identical for all strains (see legend to Table 2).

\section{Clustering}

The isolates were divided into clusters using unweighted average linkage clustering. Vibrio sp. 1 and Vibrio sp. 2 isolates were divided into two different clusters, Phenon 1 and Phenon 2, respectively (Table $3)$, no type strains being included in these clusters.

For bacteria clustered in Phenon 1 long cells could be seen after $1 \mathrm{~d}$ incubation in liquid media. When exponential-phase cultures were grown on solid media, isolates of Phenon 1 formed grey, translucent, rounded colonies up to $0.5 \mathrm{~mm}$ in diameter after $1 \mathrm{~d}$ incubation at 15 or $22{ }^{\circ} \mathrm{C}$. The colonies were viscous and adhered to the medium, forming long threads when removed from the agar surface. Haemolysis was only visible as a moderate transparency of the agar. After $2 \mathrm{~d}$ incubation the colony diameter was $1-2 \mathrm{~mm}$ and $\beta$ haemolysis was detected underneath the colonies. All the strains included in Phenon 1 survived freezing. Only three of the isolates in Phenon 1 varied from the HMO, each with regard to one character. V. marinus NCMB $1144^{\mathrm{T}}$ and $V$. ordalii NCMB $2167^{\mathrm{T}}$ were the type strains most closely related to Phenon 1, differing from the HMO of this cluster with regard to 12 and 14 characters, respectively. Among actual characters, Phenon 1 differed from both $V$. marinus NCMB $1144^{\mathrm{T}}$ and $V$. ordalii NCMB $2167^{\mathrm{T}}$ in being sensitive to penicillin, not growing in $5 \% \mathrm{NaCl}$, and in producing lysine decarboxylase, myristate lipase and acid from dextrin.

Exponential-phase bacteria clustered in Phenon 2 showed colonies $1-2 \mathrm{~mm}$ in diameter after $1 \mathrm{~d}$ incubation at 15 or $22{ }^{\circ} \mathrm{C}$, and $2-3 \mathrm{~mm}$ after $2 \mathrm{~d}$ incubation. The colonies were round and yellow, with an opaque centre and a butyrous consistence. If present, $\beta$-haemolysis only occurred when the bacteria were grown on media containing $2 \% \mathrm{NaCl}$. A haemolytic zone extending into the surrounding medium was seen after $2 \mathrm{~d}$ incubation. For isolates clustered in Phenon 2 only four isolates represented the HMO, while up to seven characters differed from the HMO.
Vibrio pelagius biotype II NCMB 2253 and $V$. logei ATCC 15382 were the reference strains most closely related to Phenon 2. V. pelagius biotype II NCMB 2253 consistently differed from Phenon 2 having white colonies and growing at $30^{\circ} \mathrm{C}$ and not at $4{ }^{\circ} \mathrm{C}$. All the other characters that differed between the HMO of Phenon 2 and $V$. pelagius biotype II NCMB 2253 varied in the Phenon 2 isolates. The single isolate of Phenon 2 that was most closely related to $V$. pelagius biotype II NCMB 2253 differed from this strain in nine characters, while the single isolate of Phenon 2 that was most closely related to $V$. logei ATCC 15382 differed from this strain in 10 characters, including its ability to hydrolyse starch and gelatin, and its inability to produce acid from cellobiose and lactose. Other tests that differed showed variable results within the Phenon 2 isolates.

\section{Ultrastructural studies}

All bacterial cells were pleomorphic, short or long, straight or curved rods. Strains in Phenon 1 had one single polar flagellum. The scanning electron micrograph of strain $88 / 478^{\mathrm{T}}$ shows that the flagellum has a diameter that is twice as large as seen in the transmission electron micrograph (Fig. 1a and b). This difference is probably caused by the two separate techniques used for electron microscopy. Preparation of bacterial cells for SEM is more gentle to the cells than preparation for TEM, possibly leaving the sheath surrounding the flagellum intact. Bacteria belonging to Phenon 2 had multiple (often 5-6) polar flagellae. As with Vibrio sp. 1 strain $88 / 478^{\mathrm{T}}$, the Vibrio sp. 2 strain $88 / 441^{\mathrm{T}}$ probably has an intact sheath around the flagella in the scanning electron micrograph while the sheath has disappeared in the transmission electron micrograph (Fig. 1c and d).

\section{Whole-cell protein gel electrophoresis and Western blotting}

Based on protein electrophoretic patterns, the strains isolated from winter ulcer could be divided into two groups, equivalent to Phenon 1 and Phenon 2, respectively (Fig. 2a). Variation in the protein electrophoresis patterns was limited both among the Vibrio sp. 1 and Vibrio sp. 2 strains. The protein patterns for the Vibrio sp. 1 strains were most similar to the pattern for $V$. marinus NCMB $1144^{\mathrm{T}}$, but differentiated from this strain by several bands. The Vibrio sp. 2 strains had patterns very similar to $V$. logei ATCC 15382 . $V$. pelagius biotype II NCMB 2253 did not, however, have many protein bands in common with the Vibrio sp. 2 strains.

In Western blotting antiserum 1 and antiserum 2 reacted with whole-cell preparations only, not with Proteinase-K-treated cells. Both antisera reacted with all the tested Vibrio species (Fig. 2b and c). Antiserum 1 gave the strongest reaction with the Vibrio sp. 1 strains and $V$. marinus (Fig. 2b). The reactions for the 
Table 3. Similarities, $S_{S M}$, between the strains based on biochemical and physiological characterization

${ }^{1}$ Selected strains from Group II described by Lunder et al. (1995). ${ }^{2}$ Selected strains from Group I described by Lunder et al. (1995)

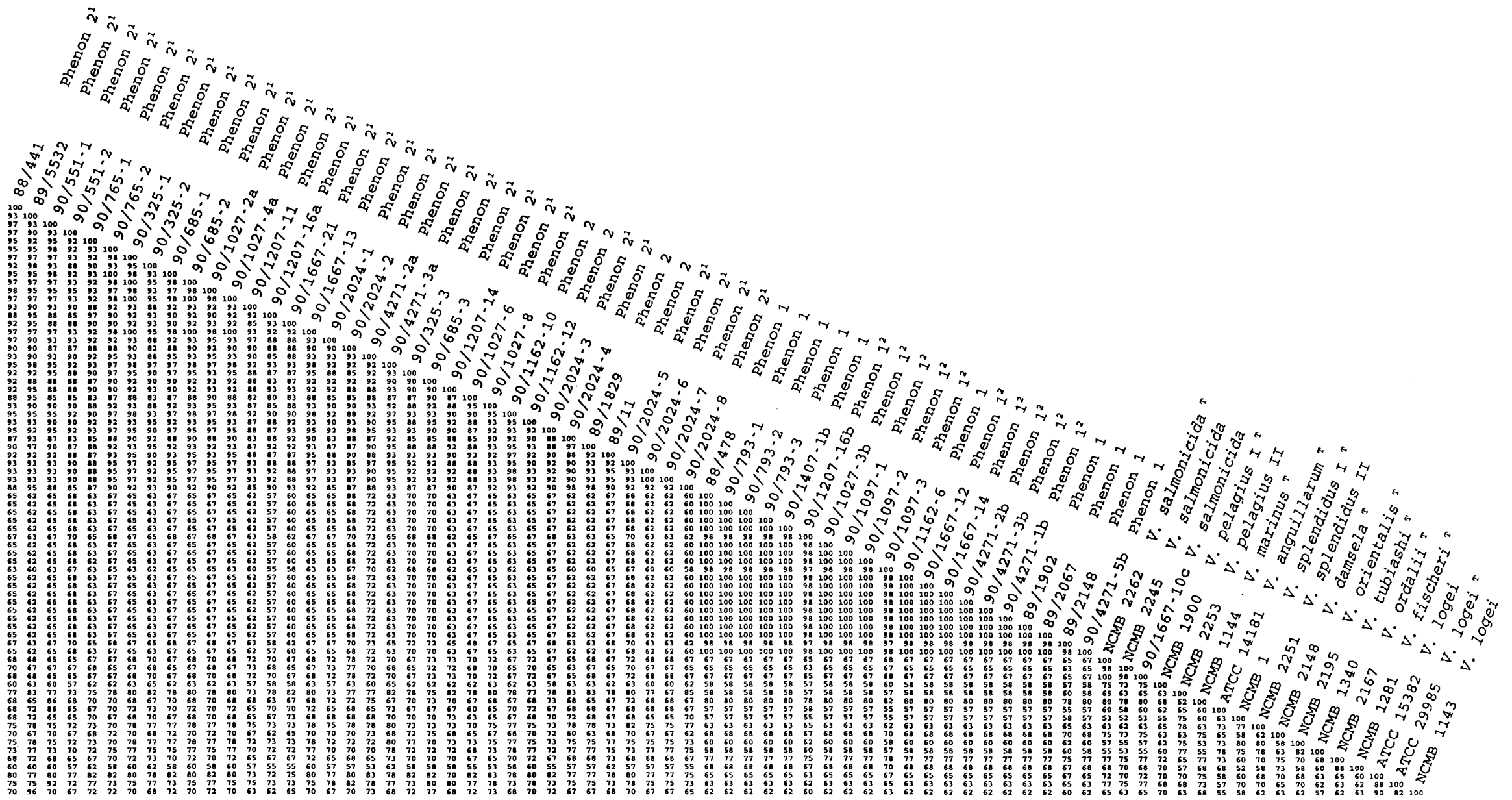



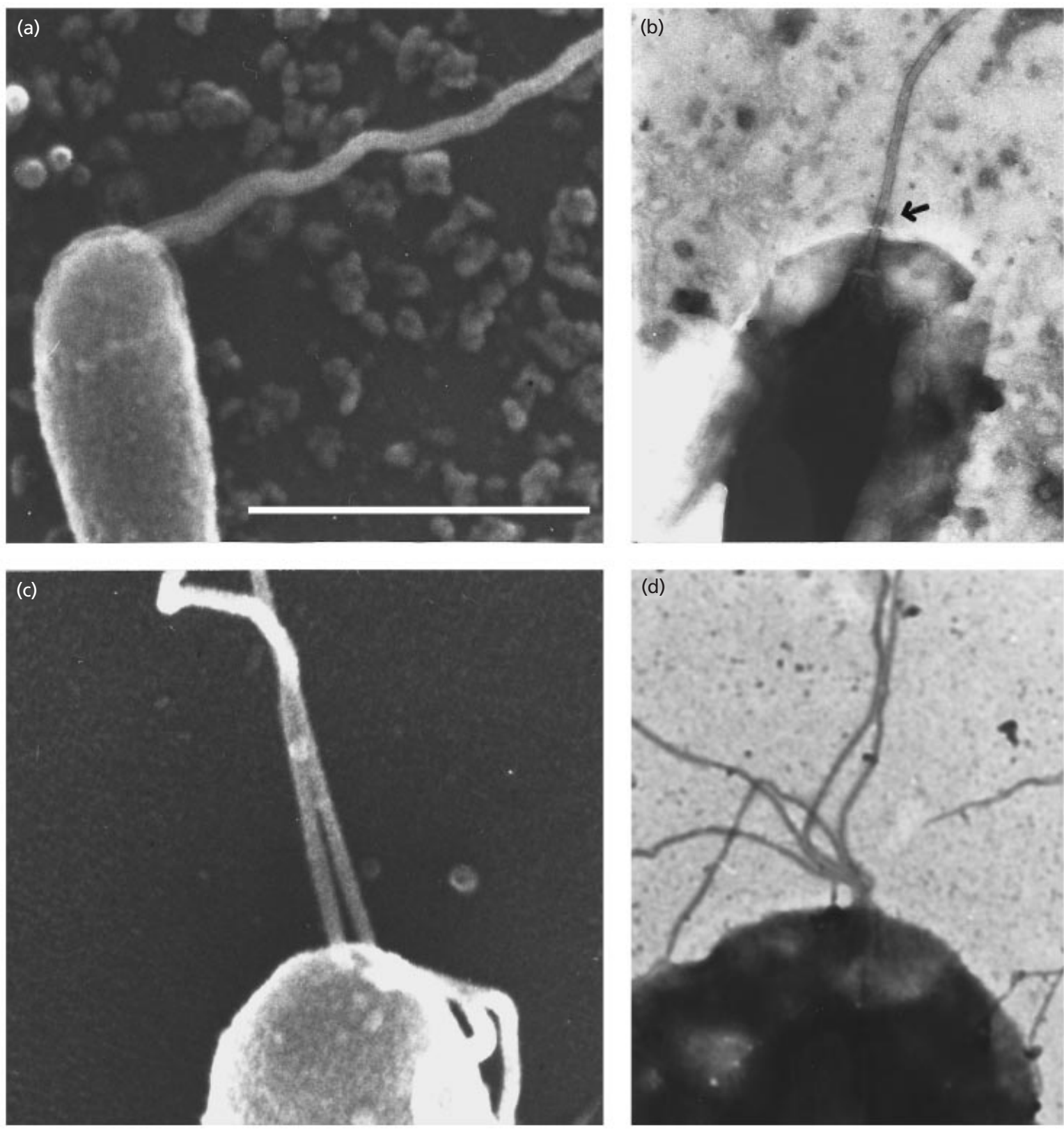

Fig. 1. (a) Scanning electron micrograph of Vibrio sp. 1 strain $88 / 478^{\top}$ (Phenon 1) and (b) transmission electron micrograph of negatively stained bacterial cells of Vibrio sp. 1 strain $88 / 478^{\top}$. (c) Scanning electron micrograph of Vibrio sp. 2 strain $88 / 441^{\top}$ (Phenon 2) and (d) transmission electron micrograph of negatively stained bacterial cells of Vibrio sp. 2 strain $88 / 441^{\top}$. Bar, $1 \mu \mathrm{m}$ (all micrographs are at the same magnification). The arrow in (b) indicates what may be remnants of the sheath surrounding the flagellum in (a).

Vibrio sp. 1 strains were identical. Electrophoretic mobility of the bands differentiated between the Vibrio sp. 1 strains and $V$. marinus. Antiserum 2 gave the strongest reaction with the Vibrio sp. 2 strains, $V$. ordalii NCMB $2167^{\mathrm{T}}, V$. anguillarum ATCC 14181, $V$. logei ATCC 15382, V. pelagius II NCMB 2253, $V$. salmonicida NCMB $2262^{\mathrm{T}}$ and $V$. logei ATCC $29985^{\mathrm{T}}$ (Fig. 2c). The reactions for the Vibrio sp. 2 strains were identical (Fig. 2c), while all the Vibrio reference strains showed moderately different profiles.

\section{Substrate gel electrophoresis}

Vibrio sp. 1 strains had identical proteinase profiles, but these profiles were different from the Vibrio sp. 2 strains (Fig. 3). The profile of $V$. ordalii was similar to the profile of the Vibrio sp. 1 strains, with only minor differences in electrophoretic mobility (Fig. 3). The Vibrio sp. 2 strains had identical proteinase profiles, these profiles being similar to $V$. logei strains ATCC 15382 and $V$. logei ATCC $29985^{\mathrm{T}}$ (Fig. 3). 
(a)
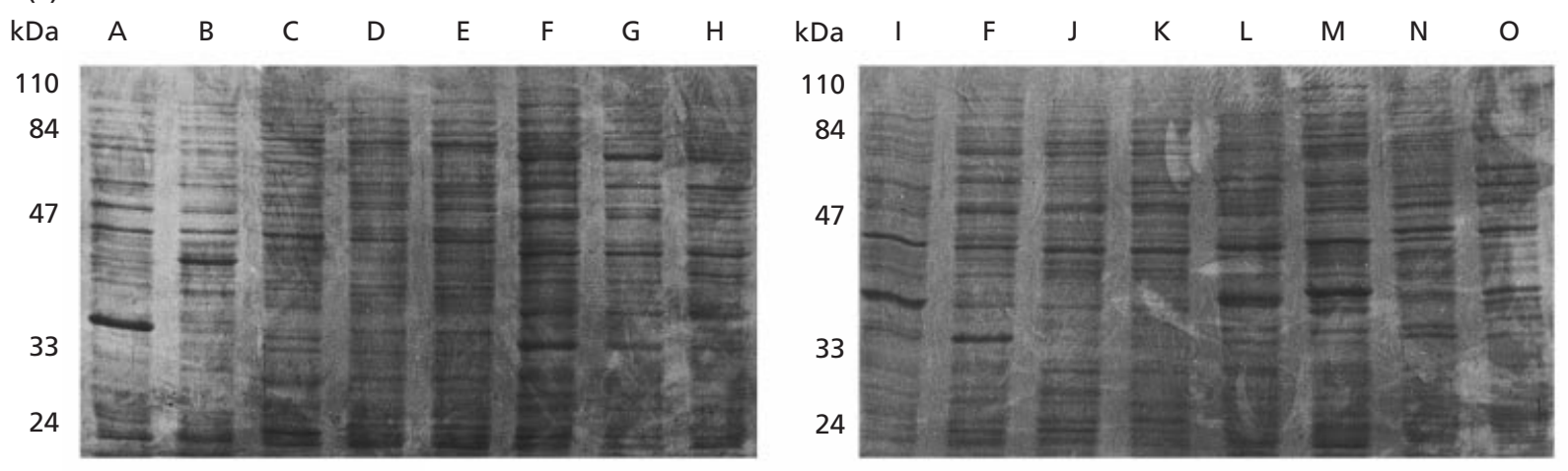

(b)
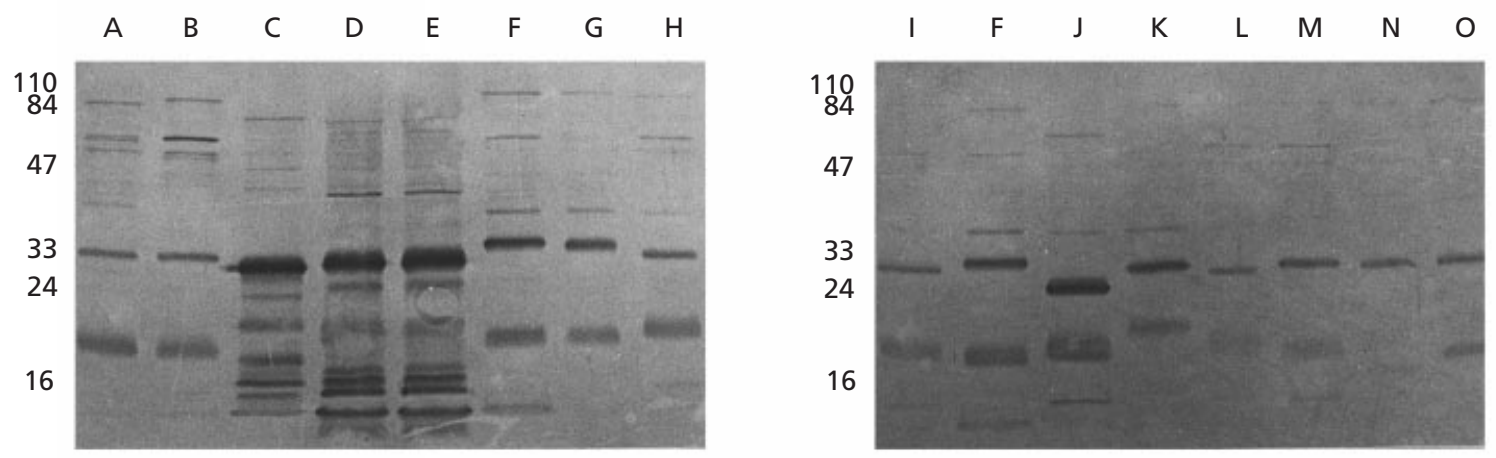

(c)
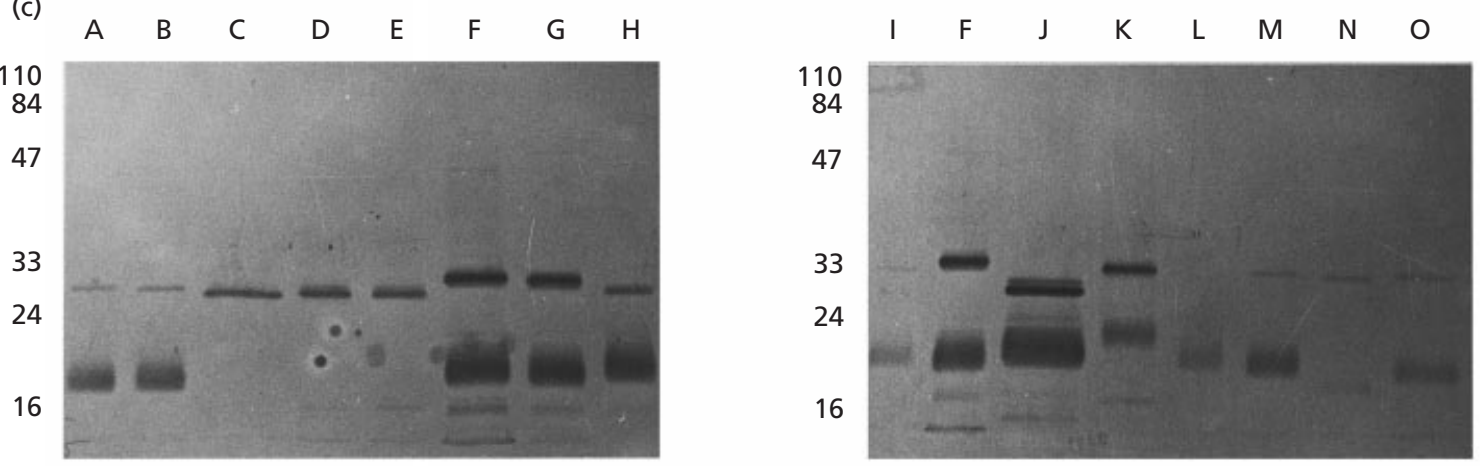

Fig. 2. SDS-PAGE of whole-cell preparations of Vibrio sp. 1 (Phenon 1), Vibrio sp. 2 (Phenon 2) and different Vibrio type and reference strains. (a) Coomassie-brilliant-blue-stained gels. (b) Western blot developed with antiserum raised against Vibrio sp. 1 (Phenon 1) 88/478 ${ }^{\top}$. (c) Western blot developed with antiserum raised against Vibrio sp. 2 (Phenon 2) 88/441 ${ }^{\top}$. Lanes: A, V. ordalii NCMB $2167^{\top} ; B, V$. anguillarum ATCC $14181 ; C, V$. marinus NCMB $1144^{\top} ; D$, Vibrio sp. 1 (Phenon 1) 88/478' ; E, Vibrio sp. 1 (Phenon 1) 90/4271-1b; F, Vibrio sp. 2 (Phenon 2) 90/325-1; G, Vibrio sp. 2 (Phenon 2) 90/685-2; H, V. logei ATCC 15382; I, V. pelagius II NCMB 2253; J, V. salmonicida NCMB 2262 ; K, V. logei ATCC 29985 ${ }^{\top}$; L, V. splendidus I NCMB $1^{\top} ;$ M, V. splendidus II NCMB 2251; N, V. pelagius I; NCMB $1900^{\top} ;$ O, V. orientalis NCMB $2195^{\top}$.

\section{Plasmid profiles}

The results of plasmid profiling presented in Tables 4 and 5 are based on repeated plasmid isolations with the three different plasmid isolation methods. The plasmid profiles of Phenon 1 isolates showed relatively limited variation, but no plasmids were common to all the isolates (Table 4). All Phenon 1 isolates harboured four or more plasmids of various sizes. Except for one plasmid, 3.9 MDa, which was missing in two of three isolates from the same origin (Table 4, fish farm c), isolates from the same farm had identical plasmid profiles.

Preparation of plasmid DNA by the alkaline lysis method (Birnboim \& Doly, 1979), produced more plasmid bands than the other methods employed; however, similar results were obtained. The additional plasmid bands observed when the alkaline lysis method was used were open circular plasmids and 

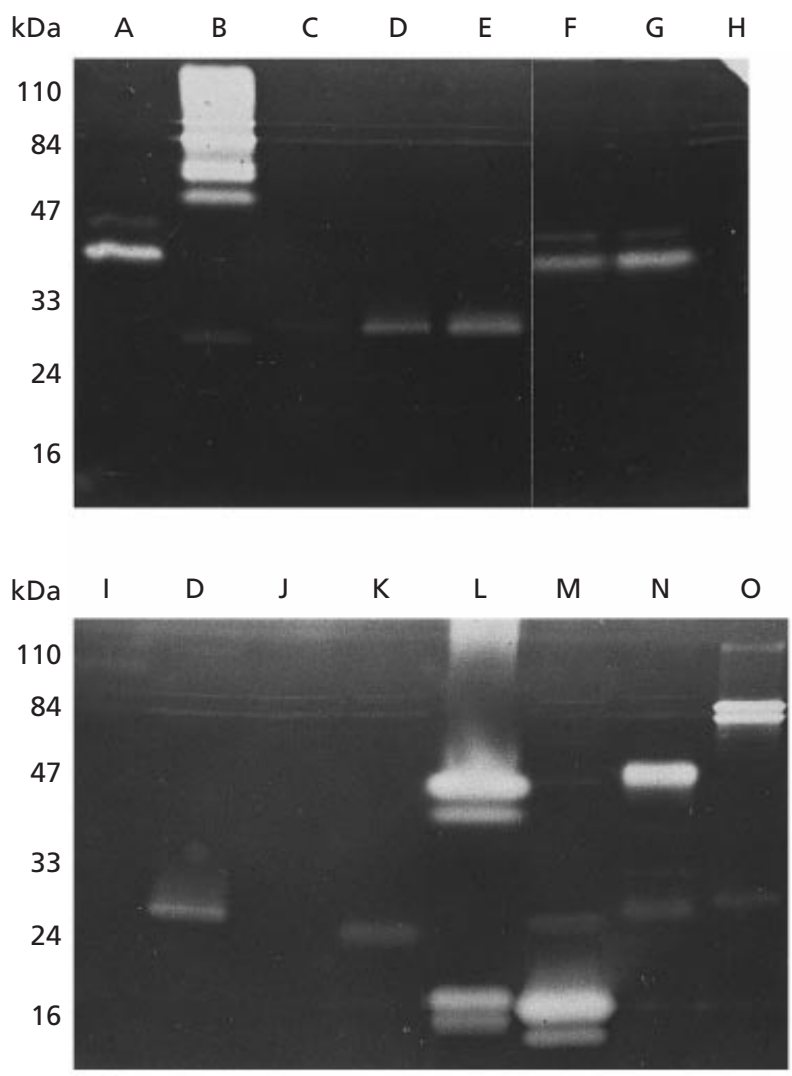

Fig. 3. Substrate gel electrophoresis of culture supernatants from Vibrio sp. 1 (Phenon 1), Vibrio sp. 2 (Phenon 2) and different Vibrio type and reference strains. Gelatin was copolymerized in the gel. Lanes: A, V. ordalii NCMB $2167^{\top} ; \mathrm{B}, \mathrm{V}$. anguillarum ATCC 14181; C, V. logei ATCC 15382; D, Vibrio sp. 2 (Phenon 2) 90/325-1; E, Vibrio sp. 2 (Phenon 2) 90/685-2; F, Vibrio sp. 1 (Phenon 1) $88 / 478^{\top}$; G, Vibrio sp. 1 (Phenon 1) 90/4271-1b; H, V. marinus NCMB $1144^{\top}$; I, V. pelagius II NCMB $2253 ;$ J, V. salmonicida NCMB $2262^{\top} ; \mathrm{K}, V$. logei ATCC $29985^{\top}$; L, V. splendidus I NCMB $1^{\top}$; M, V. splendidus II NCMB 2251; N, V. pelagius I, NCMB $1900^{\top} ; \mathrm{O}, \mathrm{V}$. orientalis NCMB $2195^{\top}$.

to some extent linearized plasmids that produced one or two extra bands from the same plasmid on the agarose gel in addition to the supercoiled plasmid band. Following HindIII digestion of the plasmid DNA, two large fragments of 9.4 and $5.4 \mathrm{~kb}$ were only detected in samples from strains with plasmids of $8 \cdot 0$ and $5.5 \mathrm{MDa}$.
The plasmid profiles within Phenon 2 were heterogeneous (Table 5). Nine isolates had no plasmids. Another group of nine isolates (the first nine isolates in Table 5) shared varying numbers of small plasmids. None of these isolates had exactly the same plasmid profile.

\section{Colony hybridization}

Colony hybridization using multiprimed HaeIIIdigested total DNA probes from representatives of Phenon 1 and Phenon 2, sorted the collection of strains isolated from Atlantic salmon suffering from winter ulcer in two groups. These two groups contain the same strains as Phenon 1 and 2 (Table 6). All Phenon 1 isolates were positive on all the membranes used when hybridized with both Phenon 1 probes. Four of the Phenon 2 isolates showed only a weak colour reaction against the two Phenon 2 probes in both parallel membranes used for each probe, or only showed hybridization on one of the two membranes.

The probes from Phenon 1 showed hybridization with $V$. anguillarum on one of four membranes and weak hybridization with $V$. marinus on two of four membranes, but not with other reference strains (Table 6).

The probes from Phenon 2 showed weak hybridization with all $V$. salmonicida and $V$. logei strains, but not with other reference strains.

\section{Total DNA agarose gel electrophoresis}

Electrophoresis of both HaeIII- and HindIII-digested total DNA (Fig. 4a and b, respectively) showed that the three isolates from Phenon 1 were similar, but that the NVI 90/4271-1b isolate was not identical to the other two (Fig. 4a and b; lanes B, C and D). Phenon 1 strains differed from all the other Vibrio strains tested. The Phenon 2 isolates showed a relatively low degree of similarity (Fig. 4a and b, lanes I-L) and they differed from both the $V$. salmonicida (lanes $\mathrm{G}$ and $\mathrm{H}$ ) and the $V$. logei isolates (lanes $\mathrm{M}$ and $\mathrm{N}$ ). The two $V$. salmonicida isolates were identical (Fig. $4 \mathrm{a}$ and b, lanes $\mathrm{G}$ and $\mathrm{H}$ ). There was no obvious similarity between the rest of the isolates based on the restriction-enzymedigested total DNA. The two $V$. logei strains, ATCC

Table 4. Plasmid profiles of $V$. viscosus (Phenon 1) isolates

\begin{tabular}{|c|c|c|c|c|c|c|c|c|c|c|c|c|c|}
\hline \multirow{2}{*}{$\begin{array}{l}\begin{array}{l}\text { No. of } \\
\text { isolates }\end{array} \\
10\end{array}$} & \multirow{2}{*}{$\begin{array}{c}\begin{array}{c}\text { Origin (fish } \\
\text { farms) }\end{array} \\
\mathrm{a}, \mathrm{b}, \mathrm{c}, \mathrm{d}, \mathrm{e}, \mathrm{f}\end{array}$} & \multicolumn{12}{|c|}{ Plasmid (MDa) } \\
\hline & & $8 \cdot 0$ & & $5 \cdot 5$ & & $3 \cdot 9$ & $3 \cdot 7$ & & $3 \cdot 0$ & & & & $2 \cdot 2$ \\
\hline 2 & $\mathrm{c}$ & $8 \cdot 0$ & & $5 \cdot 5$ & & & $3 \cdot 7$ & & $3 \cdot 0$ & & & & $2 \cdot 2$ \\
\hline 4 & $\mathrm{~g}$ & & & & & $3 \cdot 9$ & $3 \cdot 7$ & & $3 \cdot 0$ & & & & $2 \cdot 2$ \\
\hline 2 & $\mathrm{~h}, \mathrm{i}$ & $8 \cdot 0$ & & $5 \cdot 5$ & & & $3 \cdot 7$ & $3 \cdot 3$ & & $2 \cdot 8$ & & $2 \cdot 25$ & \\
\hline 1 & j & $8 \cdot 0$ & & $5 \cdot 5$ & & & $3 \cdot 7$ & & & $2 \cdot 8$ & $2 \cdot 4$ & & \\
\hline 1 & $\mathrm{k}$ & $8 \cdot 0$ & $7 \cdot 3 \quad 6 \cdot 1$ & $5 \cdot 5$ & $4 \cdot 2$ & & $3 \cdot 5$ & $3 \cdot 1$ & & & $2 \cdot 4$ & & \\
\hline
\end{tabular}


Table 5. Plasmid profiles of $V$. wodanis (Phenon 2) isolates

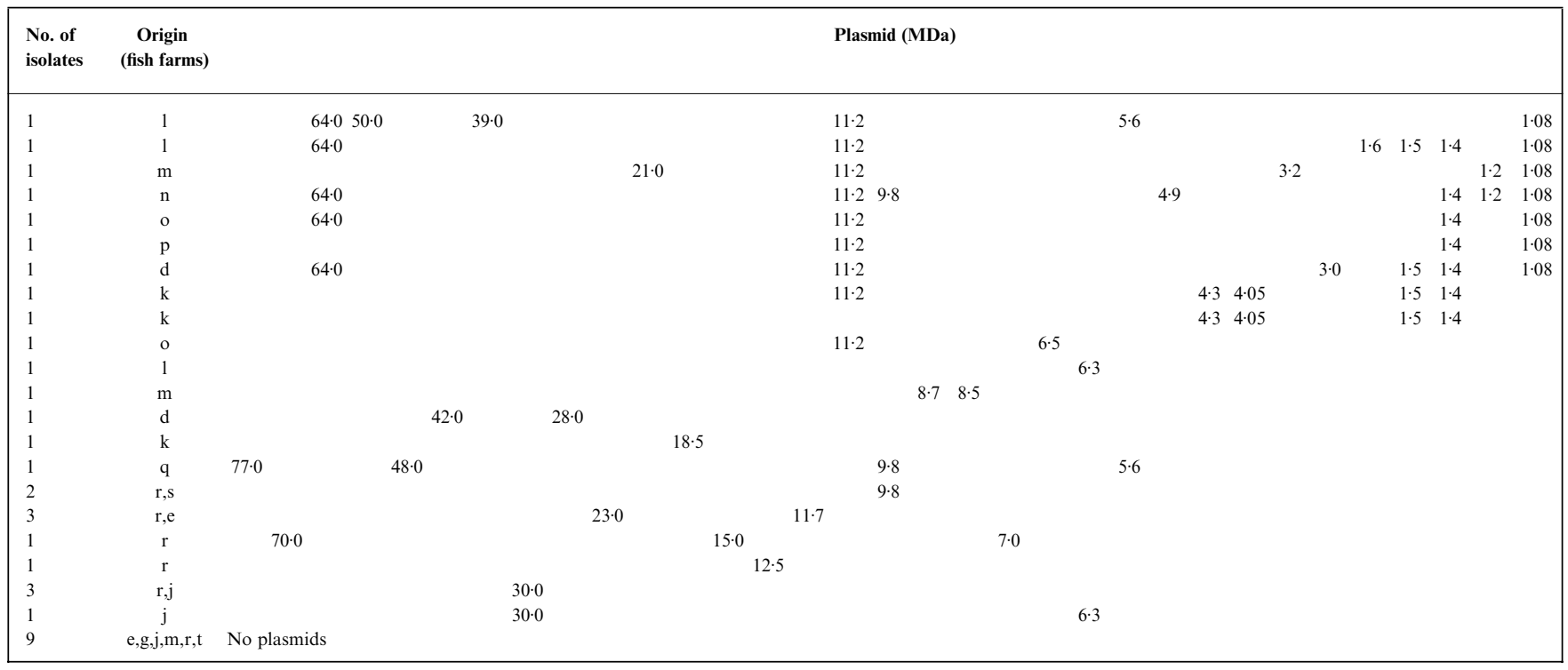

15382 and ATCC $29985^{\mathrm{T}}$, were dissimilar (Fig. 4a and $\mathrm{b}$, lanes $\mathrm{M}$ and $\mathrm{N}$ ).

\section{Southern blot hybridization}

The elution of labelled DNA was easy and efficient with the AMPPD luminescence development (Fig. 5). Certain bands hybridized in all Vibrio strains independent of the probe used. However, the intensity of these bands varied according to the probe.

When strain $88 / 478^{\mathrm{T}}$ from Phenon 1 was used as probe, all three strains from Phenon 1 showed hybridization that involved the majority of the fragments (Fig. 5a, lanes B, C and D). Although strain 90/4271-1b (Fig. 5a, lane B) showed weaker hybridization signals than the two other Phenon 1 strains, results were similar when 90/4271-1b was used as probe (data not shown). If the time of exposure was prolonged during development with AMPPD and luminescence, hybridization with strain $88 / 478^{\mathrm{T}}$ as probe was visible in all bands in $90 / 4271-1 \mathrm{~b}$ in contrast to $V$. marinus NCMB $1144^{\mathrm{T}}$. The Southern hybridization showed, however, that $V$. marinus was the reference strain most closely related to Phenon 1 isolates (Fig. 5a and b, lanes A, B, C and D), but to a lesser extent than, for instance $V$. anguillarum and $V$. ordalii, which showed similarity with each other (data not shown).

When DNA from 90/4271-1b (Phenon 1) was used as probe, one strong band, a $5.4 \mathrm{~kb}$ fragment, was missing in the 90/4271-1b digest compared to the two other strains in Phenon 1 (data not shown). When DNA from $88 / 478^{\mathrm{T}}$ was used as probe, strong signals from bands of both 5.4 and $9.4 \mathrm{~kb}$ were observed only in the lanes for $88 / 478^{\mathrm{T}}$ and $90 / 1097-1$ from Phenon 1 and not in 90/4271-1b (Fig. 5a, lanes B, C and D). Similarly a $2.0 \mathrm{~kb}$ fragment band gave strong signals only in $89 / 5532$ (Phenon 2) when $89 / 5532$ was used as probe (Fig. 5c, lane K).

Phenon 2 isolates also gave signals from the majority of bands when strains from Phenon 2 were used as probes (Fig. 5c, lanes I, L and K). Similar hybridization was also observed in V. logei ATCC 15382 (Fig. 5c, lane $\mathrm{N}$ ), though fewer fragments hybridized in $V$. logei ATCC $29985^{\mathrm{T}}$ or $V$. salmonicida (Fig. 5c, lanes M, G and $\mathrm{H}$ ). Using DNA from $V$. logei ATCC 15382 as probe revealed strong hybridization only with homologous DNA, not with Phenon 2 strains (Fig. 5d, lane N).

When the $V$. salmonicida type strain was used as probe, hybridization was obtained with both $V$. salmonicida strains and $V$. logei ATCC $29985^{\mathrm{T}}$. $V$. logei ATCC $29985^{\mathrm{T}}$ likewise hybridized as strongly with the two $V$. salmonicida strains as with the homologous DNA but not with the other $V$. logei strain, ATCC 15382 (data not shown).

The Phenon 2 isolate 90/4271-3a showed weak hybridization with the Phenon 2 target DNA, including homologous DNA and hybridization signals were only observed after prolonged exposure. A summary of the results from Southern hybridization is given in Table 7.

\section{DNA base composition}

The $\mathrm{G}+\mathrm{C}$ content of the DNA of Phenon 1 strain $88 / 478^{\mathrm{T}}$ was $42.5 \mathrm{~mol} \%$, whereas that of the DNA of Phenon 2 strain $88 / 441^{\mathrm{T}}$ was $40 \cdot 0 \mathrm{~mol} \%$. These values lie well within the accepted range of $38-51 \mathrm{~mol} \%$ for members of the genus Vibrio (Baumann \& Schubert, 1984). 
Table 6. Data from colony hybridization

Digoxigenin-labelled multiprimed HaeIII-digested total DNA from $V$. viscosus $88 / 478^{\mathrm{T}}$ and $90 / 4271-1$ b, and from $V$. wodanis $88 / 441^{\mathrm{T}}$ and $90 / 4721-3$ a were used as probes. + , Hybridization; $(+)$, weak hybridization in both parallel blots; \pm , positive and negative on the parallel blots; - , no hybridization.

\begin{tabular}{|c|c|c|c|c|}
\hline \multirow[t]{3}{*}{ Target DNA (no. of strains) } & \multicolumn{4}{|c|}{ Probe DNA } \\
\hline & \multicolumn{2}{|c|}{ V. viscosus (Phenon 1) } & \multicolumn{2}{|c|}{ V. wodanis (Phenon 2) } \\
\hline & $88 / 478^{\mathrm{T}}$ & $90 / 4271-1 b$ & $88 / 441^{\mathrm{T}}$ & $90 / 4721-3 a$ \\
\hline V. viscosus (20) & + & + & - & - \\
\hline V. wodanis (33) & - & - & $+^{*}$ & $+^{*}$ \\
\hline V. marinus ATCC $15381^{\mathrm{T}}(1)$ & - & $(+)$ & - & - \\
\hline V. anguillarum ATCC 14181 (1) & - & \pm & - & - \\
\hline $\begin{array}{l}\text { V. salmonicida ATCC } 43839^{\mathrm{T}} \text {, NCMB } 2245 \text {, } \\
\text { NVI } 90 / 1667-10 \mathrm{c}(3)\end{array}$ & - & - & $(+)$ & $(+)$ \\
\hline V. logei ATCC $29985^{\mathrm{T}}$, ATCC 15382 (2) & - & - & $(+)$ & $(+)$ \\
\hline Reference strains listed in Table 1 (28) & - & - & - & - \\
\hline A. salmonicida subsp. salmonicida (1) & - & - & - & - \\
\hline
\end{tabular}

* Four $V$. wodanis isolates showed weak hybridization or varied between the parallel blots.

\section{Hybridization with the hydroxyapatite method}

Labelled DNA from Phenon 1 strain $88 / 478^{\mathrm{T}}$ was $81-93 \%$ related ( $89 \%$ mean relatedness) to unlabelled DNAs from nine other Phenon 1 strains in reactions done at $60{ }^{\circ} \mathrm{C}$ (Table 8). Divergence within related nucleotide sequences was $0 \cdot 0-1 \cdot 5 \%$. In reactions done at $75{ }^{\circ} \mathrm{C}$, relatedness was $74-100 \% \quad(95 \%$ mean relatedness). Labelled DNA from Phenon 2 strain $88 / 441^{\mathrm{T}}$ was $66-94 \%$ related $(77 \%$ mean relatedness) to 10 other Phenon 2 strains (Table 8). Divergence within related nucleotide sequences was $0 \cdot 0-1 \cdot 5 \%$. In reactions done at $75{ }^{\circ} \mathrm{C}$, relatedness was $55-97 \%$ (76\% mean relatedness). In reciprocal reactions with labelled DNA from $88 / 478^{\mathrm{T}}$ and $88 / 441^{\mathrm{T}}$, relatedness between Phenon 1 and Phenon 2 strains at $60^{\circ} \mathrm{C}$ was 5-22\%. Relatedness of Phenon 1 to other Vibrio and Vibrio-like species was $0-43 \%$, with $V$. marinus its closest relative. Relatedness of Phenon 2 to other Vibrio and Vibrio-like species was $2-57 \%$, with $V$. logei its closest relative. In $75^{\circ} \mathrm{C}$ reactions, relatedness of Phenon 2 to $V$. logei was $38 \%$.

\section{S rDNA analysis}

The results from 16S rDNA analysis are summarized in Fig. 6. The 16S rDNA sequence from Vibrio sp. 1 strain $88 / 478^{\mathrm{T}}$ was nearly identical to the $16 \mathrm{~S}$ rDNA sequence from Moritella HAR08 and Moritella HAR13 (Urakawa et al., 1998). There was only one single base at position 101 (E. coli 16S rRNA numbering) that separated the sequence of Vibrio sp. 1 strain $88 / 478^{\mathrm{T}}$ from the two Moritella sequences. Moritella SC27 had 2 bp (positions 101 and 472) that separated its $16 \mathrm{~S}$ rDNA sequence from the sequence of
Vibrio sp. 1 strain $88 / 478^{\mathrm{T}}$. Other Moritella strains from the study of Urakawa et al. (1998) had four (SC25), five (SC22 and DSK1) and 10 (ODA02) bp that separate them from the sequence of Vibrio sp. 1 strain $88 / 478^{\mathrm{T}}$. V. marinus, proposed by Urakawa et al. (1998) to be transferred to a new genus as Moritella marina (see Discussion), has $12 \mathrm{bp}$ that separates it from the Vibrio sp. 1 strain $88 / 478^{\mathrm{T}}$ sequence $(99 \cdot 3 \%$ of the basepairs are identical). The basepairs in the Moritella strains, including $M$. marina, that deviate from the Vibrio sp. 1 strain $88 / 478^{\mathrm{T}}$ sequence are often common and are located between positions 380 and 476.

The 16S rDNA sequence from Vibrio sp. 2 strain $88 / 441^{\mathrm{T}}$ was relatively well separated from its closest neighbours with the $16 \mathrm{~S}$ rDNA sequence from $V$. salmonicida as the most similar with $98 \cdot 2 \%$ identical bases. V. logei ATCC 15382 has $98.1 \%$ identical bases, while Vibrio fischeri had $96.0 \%$ in common with Vibrio sp. 2 strain $88 / 441^{\mathrm{T}}$.

\section{DISCUSSION}

On the basis of phenotypic characterization, colony hybridization, Southern blot hybridization and hydroxyapatite hybridization, it can be concluded that the isolates in the two groups Vibrio sp. 1 and Vibrio sp. 2 from the study of Lunder et al. (1995) represent two new species. Phenotypic characterization showed that the bacteria share properties common to isolates of the genus Vibrio, according to the definitions given by Baumann \& Schubert (1984). The species names Vibrio viscosus sp. nov. and Vibrio wodanis sp. nov. are proposed for the Vibrio sp. 1 (Phenon 1) and Vibrio sp. 2 (Phenon 2) strains, respectively. 
(a)

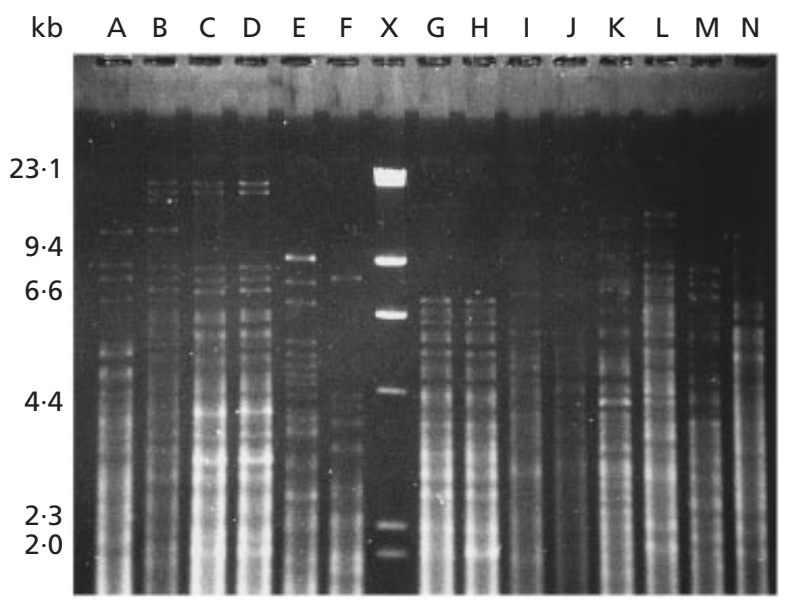

(b)

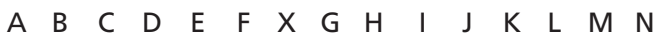

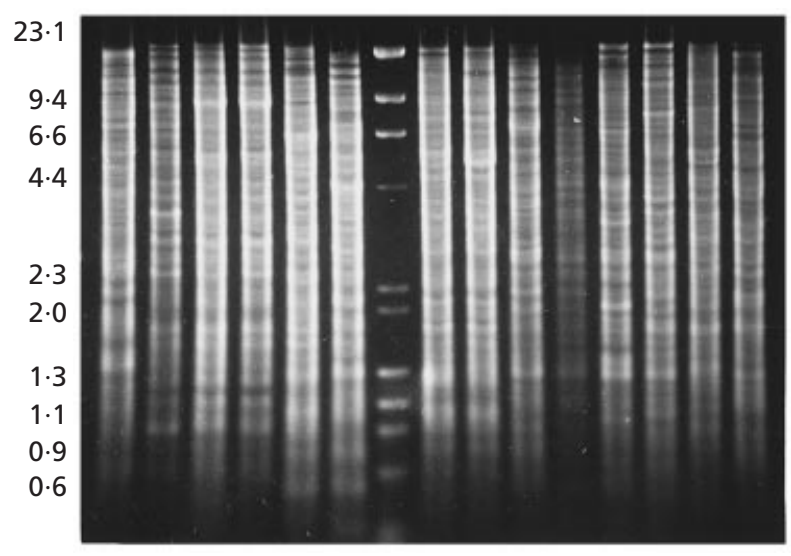

Fig. 4. Agarose gel electrophoresis of restriction enzyme digests of total DNA from different Vibrio reference strains and isolates from fish with winter ulcer. Ethidium-bromide-stained gels after electrophoresis of (a) Haelll-digested and (b) HindIIIdigested total DNAs. Lanes: $\mathrm{X}, \lambda \mathrm{DNA} /$ Hindlll fragments and ФX174 RF DNA/Haelll fragments; A, V. marinus NCMB $1144^{\top} ; \mathrm{B}$, V. viscosus (Phenon 1) 90/4271-1b; C, V. viscosus (Phenon 1) 90/1097-1; D, V. viscosus (Phenon 1) $88 / 478^{\top}$; E, V. anguillarum ATCC 14181; F, V. ordalii NCMB $2167^{\top} ; \mathrm{G}$, V. salmonicida 90/1667-10C; H, V. salmonicida NCMB $2262^{\top}$; I, V. wodanis (Phenon 2) 90/1667-13; J, V. wodanis (Phenon 2) 90/4271-3a; K, V. wodanis (Phenon 2) 89/5532; L, V. wodanis (Phenon 2) $88 / 441^{\top}$; M, V. logei ATCC 29985' ; N, V. logei ATCC 15382.

Numerical taxonomy based on physiological and biochemical characters has often been applied for differentiation of members of the Vibrionaceae, and simple matching $\left(S_{\mathrm{SM}}\right)$ and clustering using unweighted average linkage give the best result (Bryant et al., 1986). In this study clustering was performed using a program based on a given number of clusters. Wholecell protein electrophoresis patterns are valuable when comparing bacterial isolates (Jackman, 1987). In this study antisera reacted only with untreated whole-cell preparations, not with Proteinase-K-digested samples. This finding indicates that the antibodies react with protein epitopes of the cells. Other workers have shown that while substrate gel electrophoresis with gelatin as substrate is able to separate some Vibrio species, it is unable to differentiate between closely related species such as $V$. anguillarum and $V$. ordalii (Nottage \& Birkbeck, 1987). In this investigation, several different proteinase profiles were detected, indicating that the method is useful for comparison of isolates.

Physiological and biochemical characterization of the $V$. viscosus strains revealed little variability, supporting the theory that these strains represent one species. This was in agreement with the results from whole-cell protein electrophoresis, Western blotting and substrate gel electrophoresis, in which the strains were also very similar. The fact that $V$. viscosus strains had a restricted salt tolerance range not growing in 0.5 or $5 \%$ $\mathrm{NaCl}$ might explain why infection with these bacteria is limited to fish kept in sea water. Whole-cell protein electrophoresis confirmed that $V$. marinus was the species most closely resembling $V$. viscosus. In gelatin gel electrophoresis $V$. marinus did not show proteolytic activity, despite being gelatinolytic in the biochemical characterization. This might have been due to the specific conditions used in this assay. V. ordalii showed a protease profile quite similar to $V$. viscosus strains.

$V$. wodanis strains showed more variation when characterized biochemically, though results from whole-cell protein electrophoresis, Western blotting and substrate gel electrophoresis indicated that these strains are homologous and also comprise one single species. The $V$. wodanis strains in this investigation proved to be relatively closely related to the ATCC 15382 strain of $V$. logei and the $V$. pelagius biotype II strain NCMB 2253, isolated from sea water (Baumann et al., 1971; P. Baumann et al., 1980).

The limited variation among $V$. viscosus strains compared to the $V$. wodanis strains might indicate that $V$. viscosus is clinically more important and adapted to the host. The important fish pathogen A. salmonicida subsp. salmonicida also shows limited variation in phenotypical features (McCarthy \& Roberts, 1980). Challenge experiments indicate that the $V$. viscosus strains induce winter ulcer, while $V$. wodanis does not (Lunder et al., 1995). V. viscosus strains are able to produce several extracellular products that constitute possible virulence factors, being haemolytic, lecithinolytic, caseinolytic and gelatinolytic. $V$. wodanis strains also produced potential virulence factors, being haemolytic and hydrolysing gelatin, amylase and lipase. Eight of the $V$. wodanis strains produced alginase, a property differentiating the usually non-pathogenic Vibrio splendidus ( $V$. anguillarum-like bacteria) from the fish-pathogenic $V$. anguillarum (Myhr et al., 1991). $V$. viscosus and $V$. wodanis are both able to grow at low temperatures and they are isolated from fish during a period with low water temperatures (Lunder et al., 1995).

Colony hybridization was convenient for the selection of reference strains for further studies. The interpret- 
(a)

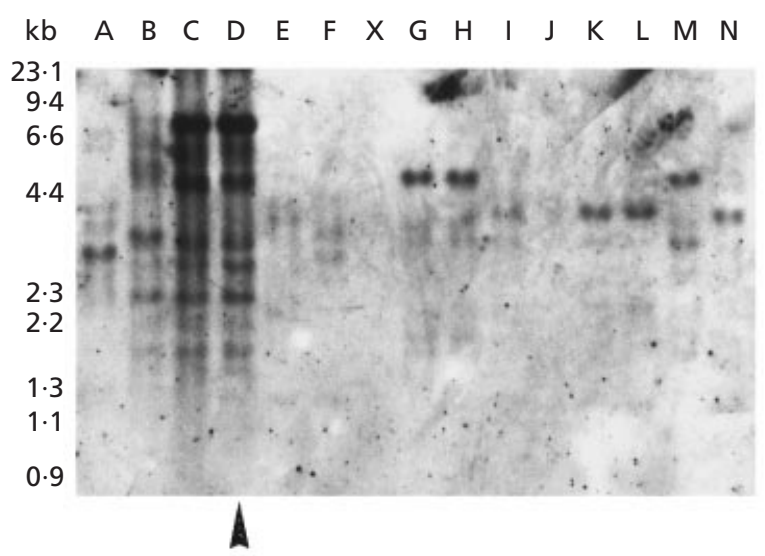

(c)
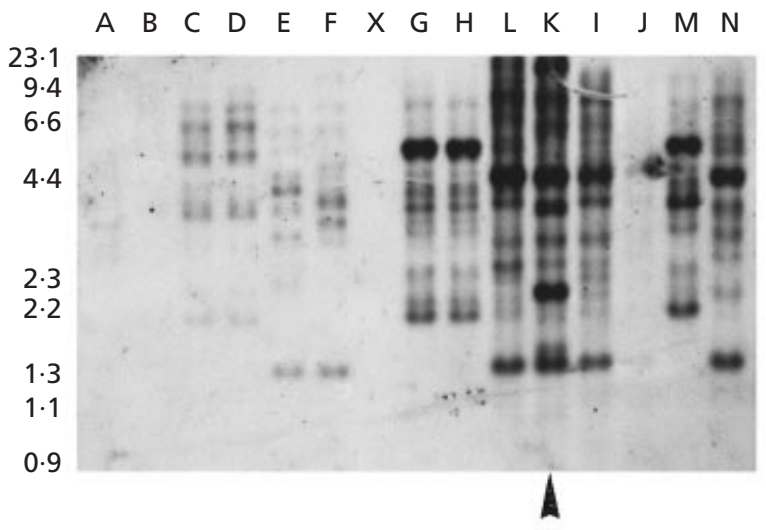

(b)
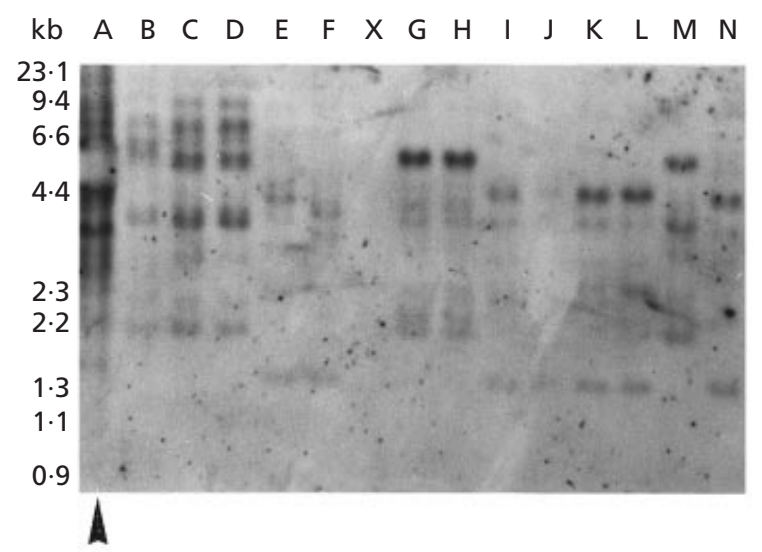

(d)

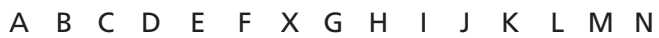

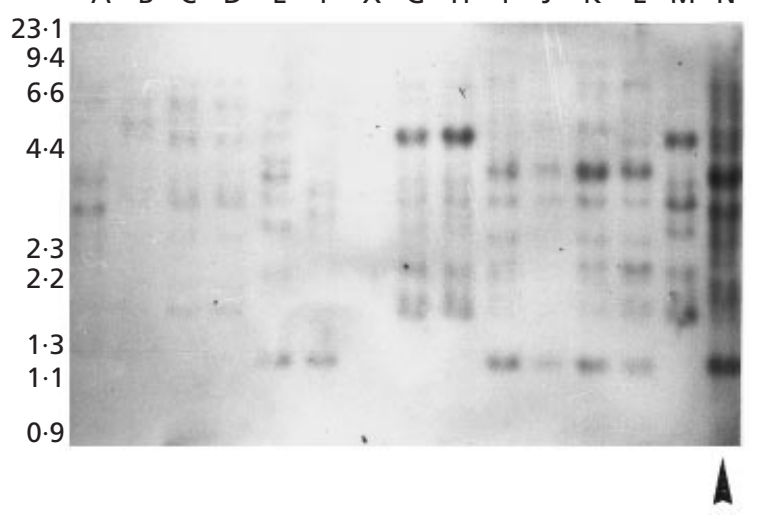

Fig. 5. Demonstration of Southern blots of total DNAs from different Vibrio reference strains and isolates from fish with winter ulcer hybridized with the following total DNA probes: (a) V. viscosus $88 / 478^{\top}$ (Phenon 1); (b) V. marinus NCMB $1144^{\mathrm{T}}$; (c) V. wodanis 89/5532 (Phenon 2); (d) V. logei ATCC 15382. The membranes were hybridized with digoxigeninlabelled probes and developed using AMPPD and luminescence. The target and probe DNAs were digested with HindIII. Lanes: $\mathrm{X}, \lambda$ DNA/HindIII fragments and $\Phi \mathrm{X} 174 \mathrm{RF}$ DNA/Haelll fragments; $\mathrm{A}, V$. marinus NCMB $1144^{\mathrm{T}} ; \mathrm{B}, V$. viscosus (Phenon 1) $90 / 4271-1 b$; C, V. viscosus (Phenon 1) 90/1097-1; D, V. viscosus (Phenon 1) 88/478 ${ }^{\top}$; E, V. anguillarum ATCC $14181 ; \mathrm{F}$, V. ordalii NCMB $2167^{\top} ; \mathrm{G}$, V. salmonicida 90/1667-10c; H, V. salmonicida NCMB $2262^{\top} ; \mathrm{I}$, V. wodanis (Phenon 2) 90/1667-13; J, V. wodanis (Phenon 2) 90/4271-3a; K, V. wodanis (Phenon 2) 89/5532; L, V. wodanis (Phenon 2) 88/441 ${ }^{\mathrm{T}}$; M, V. logei ATCC $29985^{\top}$; N, V. logei ATCC 15382. The arrowheads indicate the lanes containing target DNA of the same strain as the probe DNA.

ation of colony hybridization was relatively simple and the negative results that occurred with $V$. wodanis probes on some $V$. wodanis strains were most probably due to technical problems, i.e. colonies loosening from the membranes during the procedure. Occasional hybridization across the species level observed between $V$. anguillarum and $V$. viscosus, and between $V$. wodanis, $V$. salmonicida and $V$. logei could probably have been avoided by more stringent washing. The intention of this assay was, however, to reveal reference strains closely related to Phenon 1 and Phenon 2 strains.

Gel electrophoresis of restriction-endonucleasedigested total DNA confirmed the limited variation between the $V$. viscosus strains revealed by phenotypic characterization. $V$. wodanis strains showed, however, large variation in the length of restriction enzyme fragments between the isolates.
The relationship between the strains was elucidated in more detail in Southern hybridization than with colony hybridization. Hybridization was expressed as luminescence from AMPPD. The intensity was, however, sensitive to the amount of target DNA of each strain. Exposure of ethidium-bromide-stained agarose gels to UV light revealed the amount of DNA in each lane.

When DNA from strain 90/4271-1b ( $V$. viscosus) was used as probe, the homologous DNA showed less hybridization than the two other $V$. viscosus strains because the amount of DNA in the agarose gel was relatively small for this strain. The amount of DNA for strain 90/4271-3a (V.wodanis) was relatively even less, the hybridization being visible only after prolonged development. The other $V$. wodanis strains showed strong hybridization signals using 90/4271-3a ( $V$. wodanis) as probe. The hybridization signals were obtained from the majority of bands in $V$. wodanis 
Vibrio viscosus sp. nov. and Vibrio wodanis sp. nov.

Table 7. Data from Southern hybridization using total DNA as probe and target

+ , Hybridization in most fragments; $(+)$, hybridization restricted to a majority of the fragments; $(-)$, hybridization in a minority of the fragments; -, no hybridization or limited to a few fragments.

\begin{tabular}{|c|c|c|c|c|c|c|c|c|c|c|c|c|c|}
\hline \multirow[t]{2}{*}{ Target DNA } & \multicolumn{13}{|c|}{ Probe DNA } \\
\hline & 1 & 3 & 4 & 5 & 7 & 8 & 9 & 10 & 11 & 13 & 14 & 15 & 21 \\
\hline 1. V. viscosus $88 / 478^{\mathrm{T}}$ & + & + & - & - & - & - & - & - & - & $(-)$ & - & - & - \\
\hline 2. V. viscosus $90 / 1097-1$ & + & + & - & - & - & - & - & - & - & $(-)$ & - & - & - \\
\hline 3. V. viscosus $90 / 4271-1 \mathrm{~b}$ & + & + & - & - & - & - & - & - & - & - & - & - & - \\
\hline 4. $V$. wodanis $88 / 441^{\mathrm{T}}$ & - & - & + & + & + & + & $(-)$ & $(-)$ & - & - & - & - & - \\
\hline 5. $V$. wodanis $89 / 5532$ & - & - & $(+)$ & + & + & + & $(-)$ & - & - & - & - & - & - \\
\hline 6. $V$. wodanis $90 / 325-1$ & - & & & & + & & & & & & & & - \\
\hline 7. $V$. wodanis $90 / 4271-3 \mathrm{a}^{*}$ & - & - & $(-)$ & $(+)$ & $(+)$ & $(+)$ & - & - & - & - & - & - & - \\
\hline 8. $V$. wodanis $90 / 1667-13$ & - & - & $(+)$ & + & + & + & $(-)$ & - & - & - & - & - & - \\
\hline 9. V. logei AТCC 15382 & - & - & $(-)$ & $(+)$ & $(+)$ & $(+)$ & + & - & - & - & - & - & \\
\hline 10. V. logei ATCC $29985^{\mathrm{T}}$ & - & - & $(-)$ & $(-)$ & $(-)$ & $(-)$ & $(-)$ & + & $(+)$ & - & - & - & \\
\hline 11. V. salmonicida NCMB $2262^{\mathrm{T}}$ & - & - & $(-)$ & $(-)$ & $(-)$ & $(-)$ & $(-)$ & + & + & - & - & - & \\
\hline 12. V. salmonicida $90 / 1667-10 \mathrm{c}$ & - & - & $(-)$ & $(-)$ & - & $(-)$ & $(-)$ & + & + & - & - & - & \\
\hline 13. $V$. marinus NCMB $1144^{\mathrm{T}}$ & $(-)$ & $(-)$ & - & - & - & - & - & - & - & + & - & - & \\
\hline 14. V. anguillarum ATCC 14181 & - & - & - & - & - & - & - & - & - & - & + & $(+)$ & \\
\hline 15. V. ordalii $\mathrm{NCMB} 2167^{\mathrm{T}}$ & - & - & - & - & - & - & - & - & - & - & $(+)$ & + & \\
\hline 16. $V$. orientalis NCMB $2195^{\mathrm{T}}$ & - & & & & & - & & & & & & & - \\
\hline 17. $V$. damsela $\mathrm{NCMB} 2184^{\mathrm{T}}$ & - & & & & & - & & & & & & & - \\
\hline 18. V. vulnificus ATCC 33147 & - & & & & & - & & & & & & & - \\
\hline 19. $V$. aestuarianus NCMB $2236^{\mathrm{T}}$ & - & & & & & - & & & & & & & - \\
\hline 20. $V$. splendidus II NCMB 2251 & - & & & & & - & & & & & & & - \\
\hline 21. $V$. pelagius II NCMB 2253 & - & & & & & - & & & & & & & + \\
\hline 22. $V$. pelagius I NCMB $1900^{\mathrm{T}}$ & - & & & & & - & & & & & & & - \\
\hline 23. Y. ruckeri ATCC $29473^{\mathrm{T}}$ & - & & & & & - & & & & & & & - \\
\hline 24. A. salmonicida ATCC 14174 & - & & & & & - & & & & & & & - \\
\hline
\end{tabular}

* The amount of target DNA was relatively low.

isolates despite the fact that the RFLP patterns between the same isolates showed large variation, indicating that these strains have common sequences, but have been subject to genetic divergence.

The definition of a genetic species (genomospecies) is a group of strains whose DNAs are $70 \%$ or more related under optimal reassociation conditions and in which the related DNA sequences have diverged $5 \%$ or less (Wayne et al., 1987). A genomospecies can be easily differentiated from all other species in its genus. All of the $V$. viscosus (Phenon 1) strains were in a closely related hybridization group, conforming to this definition. They were easily differentiated from the type strains of all of the described Vibrio species as well as from a number of Vibrio-like species that have not been validly described (non-validly described species are put in quotation marks in Table 8). One of the $V$. wodanis strains $(90 / 685)$ was just less than $70 \%$ related to the labelled $V$. wodanis strain, although divergence of its related sequences was well under $5 \%$. This strain is maintained in $V$. wodanis because it fits all other criteria of the species description and because there are several strains within $V$. wodanis whose relatedness to the type strain is just over $72 \%$. V. wodanis is easily differentiated from all Vibrio and Vibrio-like species on the basis of DNA relatedness (Table 8).

The polynucleotide sequence relationship between $V$. ordalii and $V$. anguillarum strains has been estimated by Schiewe et al. (1981) to be 53-69\%. In the present investigation $V$. anguillarum was most closely related to $V$. ordalii. The difference between these strains might serve as a reference level for differentiation between species in Southern blot hybridization. There was a higher level of hybridization between $V$. salmonicida and $V$. logei strain ATCC $29985^{\mathrm{T}}$, than between $V$. anguillarum and $V$. ordalii. This might suggest that $V$. salmonicida and $V$. logei should be amalgamated into one species. This is in accordance with data from other workers (J. J. Farmer, personal communication).

$V$. logei ATCC 15382, however, did not strongly hybridize with either $V$. logei ATCC $29985^{\mathrm{T}}$ or $V$. salmonicida. This strain is more closely related to $V$. wodanis based on hybridization with various $V$. wodanis probes. When $V$.logei ATCC 15382 was used as probe, however, hybridization with $V$. wodanis was very limited. The hydroxyapatite hybridization shows conclusively that $V$. loge $i$ and $V$. wodanis are separate 
Table 8. DNA relatedness of Vibrio strains to Phenon 1 strain $88 / 478^{\top}$ and Phenon 2 strain $88 / 441^{\top}$

${ }^{32} \mathrm{P}$-labelled DNA was reacted with unlabelled DNA from the same strain (homologous reaction) and from a series of other strains (heterologous reactions). Each reaction was done at least twice. The mean association value in homologous reactions was $64 \%$ before normalization. Control reactions, in which labelled DNA was incubated in the absence of unlabelled DNA, showed $1 \cdot 7-4.9 \%$ binding to hydroxyapatite. These control values were subtracted before normalization.

\begin{tabular}{|c|c|c|c|c|c|c|}
\hline \multirow[t]{3}{*}{ Source of unlabelled DNA* } & \multicolumn{6}{|c|}{ Source of labelled DNA $\dagger$} \\
\hline & \multicolumn{3}{|c|}{ Phenon $188 / 478^{\mathrm{T}}$} & \multicolumn{3}{|c|}{ Phenon $288 / 441^{\mathrm{T}}$} \\
\hline & $\mathrm{RBR}$ at $60^{\circ} \mathrm{C}$ & D & $\begin{array}{c}\text { RBR at } \\
75^{\circ} \mathrm{C}\end{array}$ & $\mathrm{RBR}$ at $60^{\circ} \mathrm{C}$ & D & $\begin{array}{c}\text { RBR at } \\
75^{\circ} \mathrm{C}\end{array}$ \\
\hline \multicolumn{7}{|l|}{ Phenon 1} \\
\hline $88 / 478^{\mathrm{T}}$ & 100 & $0 \cdot 0$ & 100 & 22 & & \\
\hline $89 / 1407-1 b$ & 93 & $1 \cdot 5$ & 100 & 17 & & \\
\hline $89 / 1902$ & 90 & $1 \cdot 0$ & 100 & 9 & & \\
\hline $90 / 793$ & 86 & $1 \cdot 0$ & 99 & & & \\
\hline $90 / 1027-3 b$ & 93 & $1 \cdot 0$ & 94 & & & \\
\hline $90 / 1097-1$ & 86 & $0 \cdot 5$ & 97 & & & \\
\hline $90 / 1162-6$ & 90 & $0 \cdot 0$ & 98 & 12 & & \\
\hline $90 / 1667-12$ & 92 & $0 \cdot 5$ & 94 & & & \\
\hline $90 / 4271-1 b$ & 91 & $1 \cdot 5$ & 88 & & & \\
\hline $90 / 4271-5 b$ & 81 & $1 \cdot 5$ & 74 & & & \\
\hline \multicolumn{7}{|l|}{ Phenon 2} \\
\hline $88 / 441^{\mathrm{T}}$ & 16 & & & 100 & $0 \cdot 0$ & 100 \\
\hline $90 / 325$ & 15 & & & 88 & $0 \cdot 5$ & 97 \\
\hline $90 / 325-2$ & 11 & & & 94 & $0 \cdot 5$ & 95 \\
\hline $90 / 325-3$ & 5 & & & 72 & $0 \cdot 5$ & 59 \\
\hline $90 / 551-2$ & 14 & & & 77 & $0 \cdot 0$ & 77 \\
\hline $90 / 685$ & 5 & & & 66 & $1 \cdot 5$ & 55 \\
\hline $90 / 765$ & 10 & & & 72 & $1 \cdot 0$ & 76 \\
\hline $90 / 667-13$ & 8 & & & 77 & $0 \cdot 5$ & 72 \\
\hline $90 / 2024-7$ & 5 & & & 83 & $0 \cdot 5$ & 79 \\
\hline $90 / 2024-8$ & 12 & & & 72 & $1 \cdot 0$ & 81 \\
\hline $90 / 4271-3 a$ & 9 & & & 72 & $1 \cdot 0$ & 68 \\
\hline 'V. abalonicus' ATCC 27390 & 6 & & & 18 & & \\
\hline 'V. adaptus’ ATCC 19263 & 4 & & & $14+$ & & \\
\hline$V$. aestuarianus ATCC $35048^{\mathrm{T}}\left(\mathrm{NCMB} 2236^{\mathrm{T}}\right)$ & 12 & & & 14 & & \\
\hline V. alginolyticus ATCC $17749^{\mathrm{T}}\left(\mathrm{NCMB} 1903^{\mathrm{T}}\right)$ & 6 & & & 13 & & \\
\hline 'V. algosus' АTCC 14390 & 5 & & & $15+$ & & \\
\hline V. anguillarum ATCC $19264^{\mathrm{T}}$ & 10 & & & 14 & & \\
\hline V. campbellii ATCC $25920^{\mathrm{T}}$ & 6 & & & 11 & & \\
\hline$V$. carchariae ATCC $35084^{\mathrm{T}}$ & 7 & & & 11 & & \\
\hline V. cholerae ATCC $14035^{\mathrm{T}}$ & 5 & & & 9 & & \\
\hline V. cincinnatiensis ATCC $35912^{\mathrm{T}}$ & 4 & & & $12 \ddagger$ & & \\
\hline V. costicola ATCC $33508^{\mathrm{T}}$ & 4 & & & 8 & & \\
\hline 'V. cuneatus' ATCC 6972 & 1 & & & $3+$ & & \\
\hline 'V. cyclosites' ATCC 14635 & 0 & & & $2 \%$ & & \\
\hline$V$. damsela ATCC $33539^{\mathrm{T}}\left(\mathrm{NCMB} 2184^{\mathrm{T}}\right)$ & 7 & & & 12 & & \\
\hline V. diazotrophicus ATCC $33466^{\mathrm{T}}\left(\mathrm{NCMB} 2169^{\mathrm{T}}\right)$ & 8 & & & 12 & & \\
\hline V. fischeri ATCC $7744^{\mathrm{T}}\left(\mathrm{NCMB} 1281^{\mathrm{T}}\right)$ & 8 & & & 21 & & \\
\hline V. fluvialis ATCC $33809^{\mathrm{T}}\left(\mathrm{NCMB} 2249^{\mathrm{T}}\right)$ & 6 & & & 10 & & \\
\hline V. furnissii ATCC $35016^{\mathrm{T}}$ & 6 & & & 9 & & \\
\hline V. gazogenes ATCC $29988^{\mathrm{T}}$ & 6 & & & 9 & & \\
\hline$V$. harveyi ATCC $14126^{\mathrm{T}}$ & 5 & & & 11 & & \\
\hline V. hollisae ATCC $33564^{\mathrm{T}}$ & 5 & & & 12 & & \\
\hline 'V. hyperoptica' CDC 9100-79 & 3 & & & 3 & & \\
\hline
\end{tabular}


Table 8 (cont.)

\begin{tabular}{|c|c|c|c|c|c|c|}
\hline \multirow[t]{3}{*}{ Source of unlabelled DNA* } & \multicolumn{6}{|c|}{ Source of labelled DNA $\dagger$} \\
\hline & \multicolumn{3}{|c|}{ Phenon $188 / 478^{T}$} & \multicolumn{3}{|c|}{ Phenon $288 / 441^{\mathrm{T}}$} \\
\hline & $\mathrm{RBR}$ at $60^{\circ} \mathrm{C}$ & $\mathbf{D}$ & $\begin{array}{c}\text { RBR at } \\
75^{\circ} \mathrm{C}\end{array}$ & $\mathrm{RBR}$ at $60^{\circ} \mathrm{C}$ & $\mathbf{D}$ & $\begin{array}{c}\text { RBR at } \\
75^{\circ} \mathrm{C}\end{array}$ \\
\hline V. ichthyoenteri ATCC $700023^{\mathrm{T}}\left(\right.$ IFO $\left.15847^{\mathrm{T}}\right)$ & 6 & & & 18 & & \\
\hline V. iliopiscarius ATCC $51760^{\mathrm{T}}$ & 10 & & & 23 & & \\
\hline$V$. logei ATCC $29985^{\mathrm{T}}$ & 14 & & & $57+$ & & $38 \div$ \\
\hline 'V. marinofulvus' ATCC 14395 & 5 & & & $8+$ & & \\
\hline V. marinus ATCC $15381^{\mathrm{T}}\left(\mathrm{NCMB} 1144^{\mathrm{T}}\right)$ & 43 & & & 9 & & \\
\hline V. mediterranei ATCC $43341^{\mathrm{T}}$ & 5 & & & $19+$ & & \\
\hline V. metschnikovii NCTC $8443^{\mathrm{T}}\left(\mathrm{ATCC} 7708^{\mathrm{T}}\right.$ ) & 5 & & & 6 & & \\
\hline V. mimicus ATCC $33653^{\mathrm{T}}$ & 4 & & & $15+$ & & \\
\hline V. mytili CECT $632^{\mathrm{T}}$ & 4 & & & $14+$ & & \\
\hline V. natriegens ATCC $14048^{\mathrm{T}}$ & 7 & & & 14 & & \\
\hline V. navarrensis CIP $103381^{\mathrm{T}}$ & 3 & & & $7 \ddagger$ & & \\
\hline 'V. neocistes' ATCC 14636 & 0 & & & $2 \ddagger$ & & \\
\hline 'V. neptuna' CDC 9102-79 & 5 & & & $15 \%$ & & \\
\hline V. nereis ATCC $25917^{\mathrm{T}}\left(\mathrm{NCMB} 1897^{\mathrm{T}}\right)$ & 13 & & & 16 & & \\
\hline V. nigripulchritudo ATCC $27043^{\mathrm{T}}$ & 5 & & & 8 & & \\
\hline V. ordalii ATCC $33509^{\mathrm{T}}\left(\mathrm{NCMB} 2167^{\mathrm{T}}\right)$ & 4 & & & 4 & & \\
\hline V. orientalis ATCC $33934^{\mathrm{T}}\left(\mathrm{NCMB} 2195^{\mathrm{T}}\right)$ & 6 & & & 10 & & \\
\hline V. parahaemolyticus ATCC $17802^{\mathrm{T}}$ & 6 & & & $16+$ & & \\
\hline V.pelagius ATCC $25916^{\mathrm{T}}\left(\mathrm{NCMB} 1900^{\mathrm{T}}\right.$ ) & 7 & & & $17+$ & & \\
\hline$V$. penaeicida ATCC 51842 & 5 & & & 16 & & \\
\hline V. proteolyticus ATCC $15338^{\mathrm{T}}\left(\mathrm{NCMB} 1326^{\mathrm{T}}\right)$ & 4 & & & 9 & & \\
\hline 'V.psychroerythrus' ATCC 27364 & 5 & & & $6+$ & & \\
\hline V. salmonicida ATCC 43839 $\left(\mathrm{NCMB} 2262^{\mathrm{T}}\right)$ & 8 & & & 27 & & \\
\hline V. scophthalmi CECT $4638^{\mathrm{T}}$ & 4 & & & 20 & & \\
\hline V. splendidus ATCC $33125^{\mathrm{T}}\left(\mathrm{NCMB} 1^{\mathrm{T}}\right)$ & 5 & & & 13 & & \\
\hline V. tubiashii ATCC $19109^{\mathrm{T}}\left(\mathrm{NCMB} 1340^{\mathrm{T}}\right)$ & 3 & & & 10 & & \\
\hline 'V. tyrosinaticus' ATCC 19378 & 4 & & & $6 \%$ & & \\
\hline V. vulnificus ATCC $27562^{\mathrm{T}}$ & 2 & & & 6 & & \\
\hline
\end{tabular}

* Strains obtained from two different sources have the second source in parentheses.

$\uparrow \mathrm{RBR}$, relative binding ratio, expressed as a percentage; D, level of divergence, expressed as a percentage. A blank space indicates that the reaction was not done.

$\$$ These strains were tested against labelled DNA from Phenon 2 strain 90/551-2.

species. Phenotypically, $V$. wodanis and $V$.logei ATCC 15382 may be differentiated by degradation of starch and gelatin and by oxidative production of acid from cellobiose and lactose. The large number of bands hybridizing across the species level between the different vibrios included in the Southern hybridizations in this study indicates, however, that these strains have a genetic relationship within the genus level.

Southern hybridization of the $V$. viscosus isolates tested showed that $V$. marinus is the Vibrio species that is most closely related to $V$. viscosus. The crosshybridization was, however, limited.

The DNA-DNA hybridization results show that $V$. viscosus and $V$. marinus are only $43 \%$ related at the total DNA level. In addition, phenotypical tests such as lysine decarboxylase production, degradation of casein and growth at $25^{\circ} \mathrm{C}$ separates the two species. However, comparison of the $16 \mathrm{~S}$ rDNA sequence of $V$. viscosus $88 / 478^{\mathrm{T}}$ and $V$. wodanis $88 / 441^{\mathrm{T}}$ with those of other Vibrio species showed that $V$. viscosus is close to $V$. marinus (12 bp difference) and very close to two other strains ( $1 \mathrm{bp}$ difference) proposed to be members of a new genus Moritella (Urakawa et al., 1998) containing also the former $V$. marinus as the type species (M. marina). Because this nomenclature was not yet accepted during the preparation of this manuscript, we prefer to continue to use the objective synonym Vibrio marinus and to create two new Vibrio species.

The species that should be included in the genus 


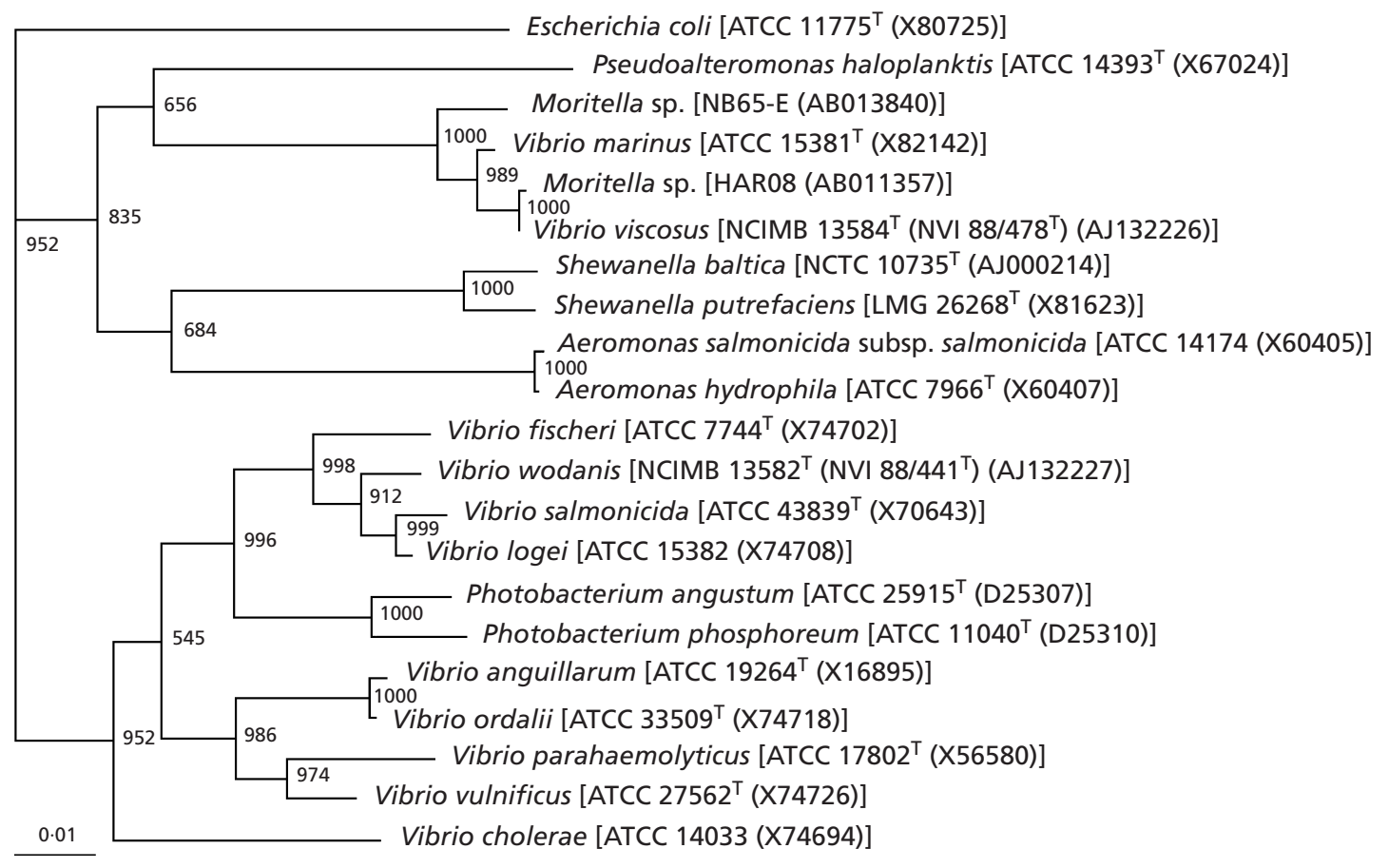

Fig. 6. Phylogenetic tree showing the relationship between Vibrio sp. 1 strain $88 / 478^{\top}$ (V. viscosus) and Vibrio sp. 2 strain $88 / 441^{\top}$ ( $V$. Wodanis) and related organisms based on complete $16 \mathrm{~S}$ rDNA sequences. The scale bar represents $1 \mathrm{nt}$ substitution per $100 \mathrm{nt}$. Bootstrap confidence values obtained from the neighbour-joining tree are given at the branch points. The reference organisms used for analysis of the $16 \mathrm{~S}$ rDNAs and their accession numbers are given in the tree.

Photobacterium present a problem that still has not been satisfactorily resolved (L. Baumann et al., 1980; Baumann et al., 1983; Gauthier et al., 1995; MacDonell \& Colwell, 1985; Reichelt et al., 1976; Smith et al., 1991). There is agreement that the genus contains Photobacterium phosphoreum, Photobacterium angustum and Photobacterium leiognathi. Some workers believe that species formerly in the genus Vibrio, $V$. fischeri, $V$. damsela and $V$. logei should be contained within the genus Photobacterium. Previous DNA relatedness studies indicated that the 'traditional' Photobacterium species are no more related to $V$. fischeri, than to any other Vibrio species (L. Baumann et al., 1980; Baumann et al., 1983; Reichelt et al., 1976). The nearest relative of Phenon 1 is $V$. marinus. The nearest relative of Phenon 2 is $V$. logei, which some consider to be a Photobacterium. We have placed both of these two new species in the genus Vibrio without prejudice, pending a final disposition of the status of the genus Photobacterium.

$V$. viscosus strains proved to be very similar genotypically, no matter which method was used. All $V$. viscosus isolates showed several plasmids and similar plasmid profiles were found among isolates from different fish farms, and indeed within the same fish farm. Investigations of HindIII-digested plasmid DNA confirmed that plasmids of similar size also had common restriction fragment lengths. The 3.9 MDa plasmid that was lacking in two out of three strains from the same fish farm, might indicate that this plasmid represents a conformational variant of another plasmid, i.e. the $3.7 \mathrm{MDa}$ plasmid.

The plasmid profile of the isolate from plaice was identical to the plasmid profile found in an isolate from Atlantic salmon. These two fish were caught at locations distant to each other. The limited variation in plasmid profiles of $V$. viscosus is parallel to the variation seen in the psychrophilic fish pathogen $V$. salmonicida (Sørum et al., 1990).

The single $5.4 \mathrm{~kb}$ band, or the two strong bands at 5.4 and $9.4 \mathrm{~kb}$, depending on which probe was used, that differentiated between $90 / 4271-1 \mathrm{~b}$ and the two other strains in $V$. viscosus, have molecular masses identical to fragments obtained from HindIII digestion of plasmids in $88 / 478^{\mathrm{T}}$ and $90 / 1097-1$. This indicates that both bands might represent fragments of plasmids which were present in multiple copies in $88 / 478^{\mathrm{T}}$ and $90 / 1097-1$, but not in 90/4271-1b. The limited variation between the $V$. viscosus isolates observed in the RFLP profiles seems to be in accordance with Southern hybridization data and plasmid profiling.

Within $V$. wodanis isolates, strong signals were detected from a $2.0 \mathrm{~kb}$ fragment in 89/5532 using DNA from this strain as probe, but not when using DNA from $88 / 441^{\mathrm{T}}, 90 / 1667-13 \mathrm{a}$ or $90 / 4271-3 \mathrm{a}$ as probes. This fragment also corresponds to a fragment obtained by HindIII digestion of 89/5532 plasmids. 
The explanation for the limited genetic divergence among isolates of the fish pathogen $A$. salmonicida subsp. salmonicida isolates has been suggested to be recent dispersion of the organism in fish farming or minimal evolutionary divergence (McCarthy \& Roberts, 1980). Such limited genetic variation might also be an expression of the great success of $A$. salmonicida subsp. salmonicida as a fish pathogen and its close adaptation to the host. Similarly, the phenotypically and genetically homologous $V$. viscosus has proven to be able to induce disease in Atlantic salmon, in contrast to the more genetically variable $V$. wodanis (Lunder et al., 1995).

However, one of the $V$. viscosus isolates originates from a plaice with skin ulcer, suggesting that these bacteria may cause skin lesions among marine fish in general. The plaice isolate $(89 / 2148)$ was phenotypically and genotypically very similar to the Atlantic salmon isolates, indicating that $V$. viscosus is not restricted to causing disease in Atlantic salmon only. Similarly, the homogeneous $V$. salmonicida also causes disease in cod (Gadus morhua) in addition to its main salmonid host, Atlantic salmon (Sørum et al., 1990).

The genetic variation between the $V$. wodanis isolates was observed in plasmid profiling, total DNA restriction enzyme fragment gel electrophoresis and Southern blotting. Nevertheless, the overall hybridization results, including the results from hydroxyapatite hybridization and phylogenetic analysis, support the view that the Phenon 2 strains comprise one species. The phenotypic characterization of these isolates also showed larger variation than found in strains of $V$. viscosus. However, several isolates from different fish farms possessed small plasmids in common, although none of these isolates had identical plasmid profiles. The two different isolates $(90 / 4271-$ $3 \mathrm{a}$ and 90/551-1) used in inoculation experiments (Lunder et al., 1995) did not have plasmids. The fact that $V$. wodanis and not $V$. viscosus were isolated in fish from two farms with winter ulcer, suggests that $V$. wodanis may participate as a secondary invader in the development of ulcers in salmon even without contribution from $V$. viscosus (Lunder et al., 1995).

\section{Description of Vibrio viscosus sp. nov.}

Vibrio viscosus (vis.co'sus. L. masc. adj. viscosus viscous, because of its thread-forming, adherent colonies).

Conforms to the description of the family Vibrionaceae and of the genus Vibrio (Baumann \& Schubert, 1984). Cells are Gram-negative, short or elongated, nonspore-forming rods that are motile by a single polar flagellum when grown on solid or in liquid media. Colonies on bovine blood agar containing $2 \% \mathrm{NaCl}$ after $48 \mathrm{~h}$ incubation at $15^{\circ} \mathrm{C}$ are round, translucent, grey, haemolytic, non-swarming and non-luminescent. Colonies are viscous and can form long threads when removed from the agar surface. Oxidase- and catalase- positive. Produce acid, but not gas aerobically and anaerobically from D-glucose. Growth occurs at 4 $25^{\circ} \mathrm{C}$, but not at $30{ }^{\circ} \mathrm{C}$. $\mathrm{NaCl}$ is required for growth, at $1-4 \%$. Negative reactions in tests for indole production and Voges-Proskauer. A majority of the strains $(95 \%)$ have a negative methyl red reaction. Lysine is decarboxylated, but arginine dihydrolase and ornithine decarboxylase tests are negative. Gelatin, casein, DNA, Tween 80, urea and lecithin are hydrolysed. A majority of the strains hydrolyse starch. Alginate and aesculin are not hydrolysed. Acid is produced from dextrin and D-galactose, but not from L-arabinose, cellobiose, glycerol, inositol, lactose, D-mannitol, D-mannose, melibiose, raffinose, Lrhamnose, salicin, D-sorbitol, sucrose, trehalose nor D-xylose. Susceptible to 2,4-diamino-6,7-diisopropylpteridine $(\mathrm{O} / 129$ vibriostatic agent), penicillin, ampicillin, sulphamethizol, oxytetracycline and oxolinic acid. The enzymes alkaline phosphatase, acid phosphatase, butyrate esterase, caprylate esterase, myristate lipase, leucine arylamidase and naphthol phosphohydrolase are produced. A minority of the strains $(5 \%)$ produce valine arylamidase. Chymotrypsinase, trypsinase, cystine arylamidase, $\alpha$-fucosidase, $\alpha$-galactosidase, $\beta$-galactosidase, $\beta$ glucoronidase, acetyl $\beta$-glucosaminidase, $\alpha$-glucosidase, $\beta$-glucosidase and $\alpha$-mannosidase are not produced. Isolated from and pathogenic for Atlantic salmon, plaice and perhaps other marine fish, causing an ulcerative skin disease called winter ulcer.

\section{Description of the type strain of Vibrio viscosus sp. nov.}

The type strain of $V$. viscosus is NVI $88 / 478^{\mathrm{T}}$, isolated in 1988 in Norway from an Atlantic salmon with winter ulcer. The characteristics of the type strain are identical to those given in the species description. The $\mathrm{G}+\mathrm{C}$ content is $42.5 \mathrm{~mol} \%$. This strain has been deposited at the National Collection of Industrial and Marine Bacteria (Aberdeen, UK) as NCIMB $13584^{\mathrm{T}}$.

\section{Description of Vibrio wodanis sp. nov.}

Vibrio wodanis (wo.da'nis. M.L. gen. n. wodanis from Wodan, the Norse god of art, culture, war and the dead, because its closest relative, Vibrio logei, also a cold water vibrio, takes its name from another Norse God, Loge).

Conforms to the description of the family Vibrionaceae and of the genus Vibrio (Baumann \& Schubert, 1984). Cells are Gram-negative, short or elongated, nonspore-forming rods that are motile by means of multiple polar flagella when grown on solid or in liquid media. Colonies on bovine blood agar containing $2 \%$ $\mathrm{NaCl}$ after $48 \mathrm{~h}$ incubation at $15^{\circ} \mathrm{C}$ are round, opaque, yellow, non-swarming and non-luminescent. Oxidaseand catalase-positive. Produce acid, but not gas from D-glucose aerobically and anaerobically. Growth occurs at $4-25^{\circ} \mathrm{C}$, but not at $30^{\circ} \mathrm{C}$. $\mathrm{NaCl}$ is required 
Table 9. Phenotypical differentiation between $V$. viscosus, $V$. wodanis and their closest relatives (Baumann et al., 1971)

\begin{tabular}{|c|c|c|c|c|c|}
\hline Phenotype & $\begin{array}{l}\text { V. } \\
\text { viscosus }\end{array}$ & $\begin{array}{c}V . \\
\text { wodanis }\end{array}$ & $\begin{array}{l}V . \\
\text { marinus }\end{array}$ & $\begin{array}{l}V . \\
\log e i^{*}\end{array}$ & $\begin{array}{c}V \cdot \\
\text { salmonicida }\end{array}$ \\
\hline $\begin{array}{l}\text { Haemolysis of bovine red blood } \\
\text { cells }\end{array}$ & + & $+\dagger$ & + & - & - \\
\hline Growth at $25^{\circ} \mathrm{C}$ & + & $+\ddagger$ & - & - & - \\
\hline Lysine decarboxylase production & + & - & - & + & - \\
\hline $\begin{array}{l}\text { Oxidative production of acid from } \\
\text { trehalose }\end{array}$ & - & + & - & + & + \\
\hline Degradation of casein & + & - & - & - & - \\
\hline
\end{tabular}

* ATCC $29985^{\mathrm{T}}$.

$\dagger 94 \%$ of the strains produce haemolysis.

$\$ 83 \%$ of the strains grow.

for growth, at $1-4 \%$. A majority of strains produce indole. Positive methyl red reaction; negative VogesProskauer reaction. Negative tests for lysine decarboxylase, arginine dihydrolase and ornithine decarboxylase. Gelatin, starch and Tween 80 are hydrolysed. A majority of the strains hydrolyse DNA. A minority of strains hydrolyse alginate, lecithin, urea and aesculin. Casein is not hydrolysed. Acid is produced from dextrin, D-mannose, D-galactose and trehalose, but not from L-arabinose, cellobiose, inositol, lactose, melibiose, raffinose, L-rhamnose, salicin nor D-xylose. A majority of strains produce acid from glycerol and sucrose, and a minority of strains produce acid from D-mannitol and D-sorbitol. The enzymes alkaline phosphatase, caprylate esterase and leucine arylamidase are produced. Butyrate esterase, valine arylamidase, acid phosphatase, naphthol phosphohydrolase and acetyl $\beta$-glucosaminidase are produced by the majority of the strains. Myristate lipase is produced by one of the strains only. Chymotrypsinase, trypsinase, cystine arylamidase, $\alpha$-fucosidase, $\alpha$-galactosidase, $\beta$-galactosidase, $\beta$-glucoronidase, $\alpha$-glucosidase, $\beta$-glucosidase and $\alpha$-mannosidase were not produced. Susceptible to 2,4-diamino-6,7-diisopropylpteridine $(\mathrm{O} / 129$ vibriostatic agent), ampicillin, sulphamethizol, oxytetracycline and oxolinic acid, and resistant to penicillin. The majority of strains (94\%) are haemolytic when grown on bovine blood agar containing $2 \% \mathrm{NaCl}$. Isolated from the lesions of Atlantic salmon with the ulcerative skin disease called winter ulcer.

\section{Description of the type strain of Vibrio wodanis sp. nov.}

The type strain of $V$. wodanis is NVI $88 / 441^{\mathrm{T}}$, isolated in 1988 in Norway from an Atlantic salmon with winter ulcer. It is housed in the bacterial culture collection of the National Veterinary Institute, Oslo, Norway. The characteristics of the type strain is as given for the species, except as follows. Hydrolysis of
DNA, but not alginate, lecithin, urea and aesculin, production of indole, oxidative production of acid from glycerol and sucrose, but not from D-mannitol and D-sorbitol. The type strain produces valine arylamidase, acid phosphatase, naphthol phosphohydrolase and acetyl $\beta$-glucosaminidase, but not butyrate esterase or myristate lipase. The type strain haemolyses bovine red blood cells. The $\mathrm{G}+\mathrm{C}$ content is $40.0 \mathrm{~mol} \%$. This strain has been deposited at the National Collection of Industrial and Marine Bacteria (Aberdeen, UK) as NCIMB $13582^{\mathrm{T}}$.

Phenotypic differentiation between $V$. viscosus, $V$. wodanis and their closest relatives is shown in Table 9.

\section{ACKNOWLEDGEMENTS}

We are grateful to T. Rolfsen, EM Unit, Department of Biology, University of Oslo, for performing the electron microscopy work and to S. Hannevik for running the DNA sequencing reactions. We wish to thank Ms C. Fjellvang for skilful technical assistance. This project was funded by the Norwegian Fisheries Research Council, Project no. 747005 1401 and the Norwegian Council of Agricultural Research, Project no. 265.605.

\section{REFERENCES}

Baumann, L., Bang, S. S. \& Baumann, P. (1980). Study of relationship among species of Vibrio, Photobacterium, and terrestrial enterobacteria by an immunological comparison of glutamine synthetase and superoxide dismutase. Curr Microbiol 4, 133-138.

Baumann, P. \& Schubert, R. H. W. (1984). Family II. Vibrionaceae Vèron 1965, 5245 ${ }^{\mathrm{AL}}$. In Bergey's Manual of Systematic Bacteriology, vol. 1, pp. 516-550. Edited by N. R. Krieg \& J. G. Holt. Baltimore: Williams \& Wilkins.

Baumann, P., Baumann, L. \& Mandel, M. (1971). Taxonomy of marine bacteria: the genus Beneckea. J Bacteriol 107, 268-294.

Baumann, P., Baumann, L., Bang, S. S. \& Woolkalis, M. J. (1980). Re-evaluation of the taxonomy of Vibrio, Beneckea, and Photobacterium: Abolition of the genus Beneckea. Curr Microbiol 4, 127-132. 
Baumann, P., Baumann, L., Woolkalis, M. J. \& Bang, S. S. (1983). Evolutionary relationships in Vibrio and Photobacterium: a basis for a natural classification. Ann Rev Microbiol 37, 369-398.

Birnboim, H. C. \& Doly, J. (1979). A rapid alkaline extraction procedure for screening recombinant plasmid DNA. Nucleic Acids Res 7, 1513-1523.

Brenner, D. J., McWhorter, A. C., Leete Knutson, J. K. \& Steigerwalt, A. G. (1982). Escherichia vulneris: a new species of Enterobacteriaceae associated with human wounds. J Clin Microbiol 15, 1133-1140.

Bryant, T. N., Lee, J. V., West, P. A. \& Colwell, R. R. (1986). Numerical classification of species of Vibrio and related genera. $J$ Appl Bacteriol 61, 437-467.

Bukhari, A. I., Shapiro, J. A. \& Adhya, S. L. (1977). DNA : Insertion Elements, Plasmids, and Episomes. Cold Spring Harbor, NY: Cold Spring Harbor Laboratory.

Colwell, R. R. \& Grimes, D. J. (1984). Vibrio diseases of marine fish populations. Helgol Meeresunters 37, 265-287.

D'Aoust, J. Y. \& Kushner, D. J. (1972). Vibrio psychroerythrus sp. n.: classification of the psychrophilic marine bacterium, NRC 1004. J Bacteriol 111, 340-342.

Davis, G. H. G. \& Park, R. W. A. (1962). A taxonomic study of certain bacteria currently classified as Vibrio species. J Gen Microbiol 27, 101-119.

Dewhirst, F. E., Paster, B. J., Olsen, I. \& Fraser, G. J. (1992). Phylogeny of 54 representative strains of species in the family Pasteurellaceae as determined by comparison of $16 \mathrm{~S}$ rRNA sequences. J Bacteriol 174, 2002-2013.

Egidius, E., Wiik, R., Andersen, K., Hoff, K. A. \& Hjeltnes, B. (1986). Vibrio salmonicida sp. nov., a new fish pathogen. Int $J$ Syst Bacteriol 36, 518-520.

Ford, J. E., Perry, K. D. \& Briggs, C. A. E. (1958). Nutrition of lactic acid bacteria isolated from the rumen. J Gen Microbiol 18, 273-284.

Gauthier, G., Lafay, B., Ruimy, R., Breittmayer, V., Nicolas, J. L., Gauthier, M. \& Christen, R. (1995). Small-subunit rRNA sequences and whole DNA relatedness concur for the reassignment of Pasteurella piscicida (Snieszko et al.) Janssen and Surgalla to the genus Photobacterium as Photobacterium damsela subsp. piscicida comb. nov. Int J Syst Bacteriol 45, 139-144.

He, M., Wilde, A. \& Kaderbhai, M. A. (1990). A simple singlestep procedure for small-scale preparation of Escherichia coli plasmids. Nucleic Acids Res 18, 1660.

Heussen, C. \& Drowdle, E. B. (1980). Electrophoretic analysis of plasminogen activators in polyacrylamide gels containing sodium dodecyl sulphate and copolymerized substrates. Anal Biochem 102, 196-202.

Hull, R. A., Gill, R. E., Hsu, P., Minshew, B. H. \& Falkow, S. (1981). Construction and expression of recombinant plasmids encoding type 1 or D-mannose-resistant pili from a urinary tract infection Escherichia coli isolate. Infect Immun 33, 933-938.

Jackman, P. J. H. (1987). Microbial systematics based on electrophoretic whole-cell protein patterns. Methods Microbiol 19, 209-225.

Kado, C. I. \& Liu, S.-T. (1981). Rapid procedure for detection and isolation of large and small plasmids. J Bacteriol $\mathbf{1 4 5}$, 1365-1373.

Kyhse-Andersen, J. (1984). Electroblotting of multiple gels: a simple apparatus without buffer tank for rapid transfer of proteins from polyacrylamide to nitrocellulose. $J$ Biochem Biophys Methods 10, 203-209.
Lachica, R. V., Genigeorgis, C. \& Hoeprich, P. D. (1971). Metachromatic agar-diffusion methods for detecting staphylococcal nuclease activity. Appl Microbiol 21, 585-587.

Laemmli, U. K. (1970). Cleavage of structural proteins during the assembly of the head of bacteriophage T4. Nature 227, 680-685. Lessel, E. F. (1962). Bacterial type cultures of the American Type Culture Collection. Int Bull Bacteriol Nomencl Taxon 12, 71-88.

Lunder, T., Evensen, Ø., Holstad, G. \& Håstein, T. (1995). 'Winter ulcer' in the Atlantic salmon Salmo salar. Pathological and bacteriological investigations and transmission experiments. Dis Aquat Org 23, 39-49.

McCarthy, D. H. \& Roberts, R. J. (1980). Furunculosis of fish - the present state of our knowledge. Adv Aquatic Microbiol 2, 293-341.

MacDonell, M. T. \& Colwell, R. R. (1985). Phylogeny of the Vibrionaceae, and recommendation for two new genera, Listonella and Shewanella. Syst Appl Microbiol 6, 171-182.

Macrina, F. L., Kopecko, D. J., Jones, K. R., Ayers, D. J. \& McCowen, S.M. (1978). A multiple plasmid-containing Escherichia coli strain: convenient source of size reference plasmid molecules. Plasmid 1, 417-420.

Mandel, M., Igambi, L., Bergendahl, J., Dodson, M. L., Jr \& Scheltgen, E. (1970). Correlation of melting temperature and cesium chloride buoyant density of bacterial deoxyribonucleic acid. J Bacteriol 101, 333-338.

Maniatis, T., Fritsch, E. F. \& Sambrook, J. (1982). Molecular Cloning: a Laboratory Manual. Cold Spring Harbor, NY : Cold Spring Harbor Laboratory.

Mardia, K. V., Kent, J. T. \& Bibby, J. M. (1979). Cluster analysis. In Multivariate Analysis, pp. 360-393. Edited by K. V. Mardia, J. T. Kent \& J. M. Bibby. London: Academic Press.

Miller, J. H. (1972). Experiments in Molecular Genetics. Cold Spring Harbor, NY: Cold Spring Harbor Laboratory.

Myhr, E., Larsen, J. L., Lillehaug, A., Gudding, R., Heum, M. \& Håstein, T. (1991). Characterization of Vibrio anguillarum and closely related species isolated from farmed fish in Norway. Appl Environ Microbiol 57, 2750-2757.

Nottage, A. S. \& Birkbeck, T. H. (1987). Production of proteinase during experimental infection of Ostrea edulis L. larvae with Vibrio alginolyticus NCMB 1339 and the antigenic relationship between proteinases produced by marine vibrios pathogenic for fish and shellfish. J Fish Dis 10, 265-273.

Pettersson, B., Uhlén, M. \& Johansson, K.-E. (1996). Phylogeny of some mycoplasmas from ruminants based on $16 \mathrm{~S}$ rRNA sequences and definition of a new cluster within the hominis group. Int J Syst Bacteriol 46, 1093-1098.

Pienta, P. \& Tang, J. (editors) (1996). ATCC Bacteria and Bacteriophages, 19th edn, p. 424. Rockville, MD: American Type Culture Collection.

Reichelt, J. L., Baumann, P. \& Baumann, L. (1976). Study of genetic relationships among marine species of the genera Beneckea and Photobacterium by means of in vitro DNA/DNA hybridization. Arch Microbiol 110, 101-120.

Rockey, D. D., Fryer, J. L. \& Rohovec, J. S. (1988). Separation and in vivo analysis of two extracellular proteases and the Themolysin from Aeromonas salmonicida. Dis Aquat Org 5, 197-204.

Saitou, N. \& Nei, M. (1987). The neighbor-joining method: a new method for reconstructing phylogenetic trees. Mol Biol Evol 4, 406-425.

Sandvik, O. \& Hagen, O. (1968). Serological studies on 
proteinases produced by Aeromonas salmonicida and other aeromonads. Acta Vet Scand 9, 1-9.

Schiewe, M. H., Trust, T. J. \& Crosa, J. H. (1981). Vibrio ordalii sp. nov.: a causative agent of vibriosis in fish. Curr Microbiol 6 , 343-348.

Smith, S. K., Sutton, D. C., Fuerst, J. A. \& Reichelt, J. L. (1991). Evaluation of the genus Listonella and reassignment of Listonella damsela (Love et al.) MacDonell and Colwell to the genus Photobacterium as Photobacterium damsela comb. nov. with an emended description. Int J Syst Bacteriol 41, 529-534.

Sneath, P. H. A. \& Skerman, V. B. D. (1966). A list of type and reference strains of bacteria. Int J Syst Bacteriol 16, 1-133.

Sørum, H., Hvaal, A. B., Heum, M., Daae, F. L. \& Wiik, R. (1990). Plasmid profiling of Vibrio salmonicida for epidemiological studies of cold-water vibriosis in Atlantic salmon (Salmo salar) and cod (Gadus morhua). Appl Environ Microbiol 56, 1033-1037.

Southern, E. M. (1975). Detection of specific sequences among DNA fragments separated by gel electrophoresis. J Mol Biol 98, 503-517.
Thompson, J. D., Higgins, D. G. \& Gibson, T. J. (1994). CLUSTAL $\mathrm{W}$ : improving the sensitivity of progressive multiple sequence alignment through sequence weighting, position-specific gap penalties and weight matrix choice. Nucleic Acids Res 22, 4673-4680.

Urakawa, H., Kita-Tsukamoto, K., Steven, S. E., Ohwada, K. \& Colwell, R. R. (1998). A proposal to transfer Vibrio marinus (Russell 1891) to a new genus Moritella gen. nov. as Moritella marina comb. nov. FEMS Microbiol Lett 165, 373-378.

Wayne, L. G., Brenner, D. J., Colwell, R. R. \& 9 other authors (1987). International Committee on Systematic Bacteriology. Report of the ad hoc committee on reconciliation of approaches to bacterial systematics. Int J Syst Bacteriol 37, 463-464.

West, P. A. \& Colwell, R. R. (1984). Identification and classification of Vibrionaceae - an overview. In Vibrios in the Environment, pp. 285-363. Edited by R. R. Colwell. New York: Wiley.

ZoBell, C. E. \& Upham, H. C. (1944). A list of marine bacteria including descriptions of sixty new species. Bull Scripps Inst Oceanogr Univ Calif 5, 239-292. 